Cellular/Molecular

\title{
Kalirin-7 Is Required for Synaptic Structure and Function
}

\author{
Xin-Ming Ma, ${ }^{\star}$ Drew D. Kiraly, ${ }^{\star}$ Eric D. Gaier, Yanping Wang, Eun-Ji Kim, Eric S. Levine, Betty A. Eipper, and \\ Richard E. Mains \\ Department of Neuroscience, University of Connecticut Health Center, Farmington, Connecticut 06030
}

Rho GTPases activated by GDP/GTP exchange factors (GEFs) play key roles in the developing and adult nervous system. Kalirin-7 (Kal7), the predominant adult splice form of the multifunctional Kalirin RhoGEF, includes a PDZ [postsynaptic density-95 (PSD-95)/Discs large (Dlg)/zona occludens-1 (ZO-1)] binding domain and localizes to the postsynaptic side of excitatory synapses. In vitro studies demonstrated that overexpression of Kal7 increased dendritic spine density, whereas reduced expression of endogenous Kal7 decreased spine density. To evaluate the role of Kal7 in vivo, mice lacking the terminal exon unique to Kal7 were created. Mice lacking both copies of the $\mathrm{Kal} 7$ exon $\left(\mathrm{Kal}^{\mathrm{KO}}\right)$ grew and reproduced normally. Golgi impregnation and electron microscopy revealed decreased hippocampal spine density in Kal ${ }^{\mathrm{KO}}$ mice. Behaviorally, $\mathrm{Kal} 7{ }^{\mathrm{KO}}$ mice showed decreased anxiety-like behavior in the elevated zero maze and impaired acquisition of a passive avoidance task, but normal behavior in open field, object recognition, and radial arm maze tasks. Kal $7^{\mathrm{KO}}$ mice were deficient in hippocampal long-term potentiation. Western blot analysis confirmed the absence of Kal7 and revealed compensatory increases in larger Kalirin isoforms. PSDs purified from the cortices of Kal $7^{\mathrm{KO}}$ mice showed a deficit in Cdk5, a kinase known to phosphorylate Kal7 and play an essential role in synaptic function. The early stages of excitatory synaptic development proceeded normally in cortical neurons prepared from Kal ${ }^{\mathrm{KO}}$ mice, with decreased excitatory synapses apparent only after $21 \mathrm{~d}$ in vitro. Expression of exogenous Kal7 in Kal $7{ }^{\mathrm{KO}}$ neurons rescued this deficit. Kal7 plays an essential role in synaptic structure and function, affecting a subset of cognitive processes.

Key words: dendritic spine; hippocampus; Golgi method; LTP; passive avoidance; anxiety; PSD; Cdk5

\section{Introduction}

Alterations in the placement, prevalence, and structure of dendritic spines, the site of most glutamatergic, excitatory endings in the brain, play a critical role in the synaptic plasticity underlying learning and memory (Yuste and Bonhoeffer, 2001; Ehlers, 2002; Dunaevsky and Mason, 2003; Craig et al., 2006; Knott et al., 2006; Araya et al., 2007; Craig and Kang, 2007; McAllister, 2007). Spines change in response to stimuli producing long-term potentiation (LTP) or long-term depression (Geinisman et al., 2000; Mezey et al., 2004). In vivo, learning tasks, memory tasks, electroconvulsive shock, and exposure to hormones, cocaine, or ethanol alter spine morphology and function (Robinson et al., 2001; Fukazawa et al., 2003; Norrholm et al., 2003; Li et al., 2004; Knott et al., 2006; Lisman and Raghavachari, 2006; Jelks et al., 2007; McAllister, 2007). Inherited conditions associated with mental retardation and neurologic/psychiatric abnormalities are often

Received Sept. 7, 2008; revised 0ct. 5, 2008; accepted 0ct. 6, 2008.

This work was supported by National Institutes of Health Grants R01-DA15464 (B.A.E.), R21-18274 (R.E.M.), R01-DA16791 (E.S.L.), and T32-NS41224 (D.D.K., E.D.G.). We thank Darlene D'Amato for making the Neuropeptide Laboratory run. We especially thank Dr. Srdjan Antic, who gave generously of his time and talents in getting the electrophysiological studies going, and Dr. Fouad Lemtiri-Chlieh, who participated in exploratory electrophysiological studies. We especially thank Dr. Caiying Guo of the University of Connecticut Gene Targeting and Transgenic Facility for enormous help in constructing these mouse lines, and Maya Yankova of the University of Connecticut EM Facility for beautiful electron micrographs.

*X.-M.M. and D.D.K. contributed equally to this work.

Correspondence should be addressed to Richard E. Mains, Department of Neuroscience, University of Connecticut Health Center, 263 Farmington Avenue, Farmington, CT 06030-3401.E-mail: mains@uchc.edu.

DOI:10.1523/JNEUROSCI.4269-08.2008

Copyright $\odot 2008$ Society for Neuroscience ～0270-6474/08/2812368-15\$15.00/0 associated with spine abnormalities and have revealed key roles for small GTP binding proteins of the Rho family (Meredith et al., 2000; Norrholm and Ouimet, 2000; Ramakers, 2000; Hill et al., 2006; Tabuchi et al., 2007).

Variations in spine size and shape affect signal transmission by AMPA and NMDA receptors localized to the postsynaptic density (PSD). The PSD is a complex, 1.1 GDa molecular machine, with its many components arrayed in a tightly controlled but dynamic manner; proteomic approaches (Béique et al., 2006; Collins et al., 2006; Elias et al., 2006; Sheng and Hoogenraad, 2007) reveal the presence of 300 copies of PSD-95 and 15-20 tetrameric NMDA and AMPA receptors in the typical cortical PSD. Kalirin-7 (Kal7) is the only Rho GDP/GTP exchange factor (RhoGEF) identified in purified PSDs (Penzes et al., 2001; Collins et al., 2006; Sheng and Hoogenraad, 2007). Cyclin-dependent kinase 5 (Cdk5), a Ser/Thr kinase localized to the PSD and known to phosphorylate several proteins critical to synaptic function (Morabito et al., 2004; Cheung et al., 2006; Cheung and Ip, 2007; Zhang et al., 2008), also phosphorylates Kal7, altering its effects on spine morphology (Xin et al., 2008).

Kal7 is colocalized with PSD-95, AMPA and NMDA receptors at excitatory synapses on the dendritic spines of CA1 hippocampal pyramidal neurons and the dendritic shafts of hippocampal GABAergic interneurons (Ma et al., 2008). Expression of Kal7 increases during the time of maximal synaptogenesis in the hippocampus (Ma et al., 2003, 2008). In vitro studies point to an important role for Kal7 in synaptic function. Exogenous Kal7 caused spine formation in aspiny GABAergic interneurons, whereas decreased expression of endogenous Kal7 caused the loss 
A.

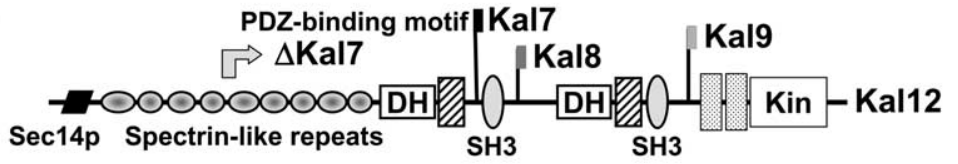

B.
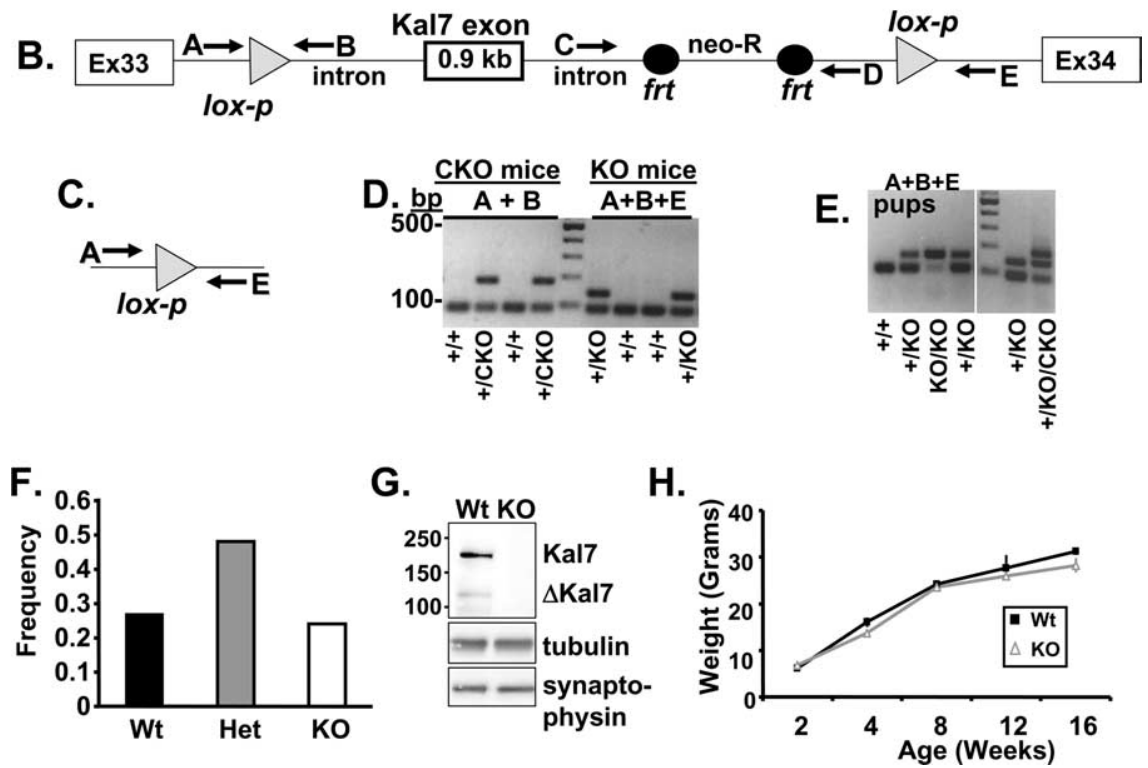

Figure 1. Kal7 knock-out strategy. A, The major isoforms of Kalirin are shown; alternative splicing of three different $3^{\prime}$ untranslated regions generates Kal7, Kal8, and Kal9. Use of a promoter located in the intron preceding exon 11 (which encodes spectrin repeat 5) yields $\Delta \mathrm{Kal7}$. Sec14p, Homologous to yeast Sec14p; SH3, Src homology 3 domain; DH, Dbl homology domain; Kin, Ser/Thr protein kinase domain. $\boldsymbol{B}$, The gene targeting approach used to eliminate the Kal7 exon, a $0.9 \mathrm{~kb} 3^{\prime}$-terminal exon situated between exons 33 and 34 , is shown (not to scale); lox-p, neomycin-resistance, frt sites and primers are indicated. Product $\mathrm{A} / \mathrm{B}$ had the expected sequence. $C$, The genomic product created by the action of FRT ( frt) and (re (lox-p) recombinase is shown; $P C R$ primers used to detect excision are shown; product A/E exhibited the correct sequence. $D, P C R$ genotyping of progeny from a $\mathrm{Kal}^{+/ \mathrm{CKO}}$ cross with C57BL/6 mouse (CKO mice) and from a Kal7 ${ }^{+/ \mathrm{CKO}}$ cross with a female expressing (re recombinase in the germ cells (KO mice). $E$, PCR genotyping of pups from a Kal7 $7^{+/ K 0} \times \mathrm{Kal} 7^{+/ K 0}$ mating; under the conditions used, primer pair A/E only yielded product from the knock-out allele; controls are shown to right of molecular weight ladder. $F, \mathrm{Kal}^{+/ \mathrm{KO} 0}$ and Kal $7^{\mathrm{KO}}$ mice were born in the expected mendelian ratio when $\mathrm{Kal} 7^{+/ K 0}$ mice were mated $(N=377$ animals). $\mathbf{G}$, Western blot analysis of cerebral cortex from wild-type and Kal $7^{\mathrm{K} 0}$ adult mice. SDS lysates (30 $\mu \mathrm{g}$ protein) were analyzed using Kal7-specific antibody (JH2959), with tubulin and synaptophysin as loading controls. $\boldsymbol{H}$, Growth curve for male $\mathrm{Kal}{ }^{\mathrm{KO}}$ mice and wild-type littermate controls ( $n=7-15$ at each time point). Error bars indicate SEM.

of excitatory synapses (Ma et al., 2008). The interactions of Kal7 with postsynaptic density-95 (PSD-95)/Discs large (Dlg)/zona occludens-1 (ZO-1) (PDZ) domain proteins such as AF-6 (Xie et al., 2008) and PSD-95 (Penzes et al., 2001), coupled with the actions of the Sec14p, spectrin-like, and GEF domains it shares with the larger isoforms of Kalirin (Schiller et al., 2005, 2008), all contribute to its actions.

Because in vitro studies do not always accurately indicate in vivo function (Varoqueaux et al., 2006; Chubykin et al., 2007; Tabuchi et al., 2007), we engineered a mouse lacking the unique exon that defines Kal7. Despite the existence of 69 RhoGEFs (Rossman et al., 2005), lack of this isoform of Kalirin results in a decreased number of dendritic spines and excitatory synapses. In addition to morphological changes, mice lacking Kal7 and $\Delta$ Kal7 (Fig. 1A) exhibit decreased anxiety-like behavior, deficits in hippocampal-dependent learning, and diminished long-term potentiation. The decreased levels of Cdk5 found in PSDs purified from Kal7 ${ }^{\mathrm{KO}}$ mice may contribute to many of these deficits.

\section{Materials and Methods}

Creation of the Kal7 conditional and total null mice

The basic strategy for creation of the conditional knock-out (KO) is diagramed in Figure $1 B$. The Kal7 exon, which encodes the 20 aa unique to Kal7 and $\Delta \mathrm{Kal} 7$, is $0.9 \mathrm{~kb}$ in length and is flanked by introns that are $18 \mathrm{~kb}$ (upstream) and $36 \mathrm{~kb}$ (downstream). Lox-p sites were introduced $1.7 \mathrm{~kb}$ upstream (nucleotide 34155267 , mm9, July 2007) and $2.0 \mathrm{~kb}$ downstream of the Kal7 exon (924 nt) (nucleotide 34150670). The neomycin resistance cassette was used in cell selection and was removed by passage through flipper female mice (Farley et al., 2000). The conditional knock-out $\left(\mathrm{Kal} 7^{\mathrm{CKO} /+}\right)$ was bred for 10 generations into C57BL/6 females from The Jackson Laboratory. To remove the Kal7 exon, $\mathrm{Kal} 7^{\mathrm{CKO} /+}$ males were bred with Hprt-Cre females (Jackson no. 004302) and the progeny were then bred into the C57BL/6 background; these mice lack $4.6 \mathrm{~kb}$ of chromosome 16 and retain the lox-p sequence (ATAACTTCGTATAATGTATGCTATACGAAGTTAT) (Fig. 1C). Experiments reported here used mice backcrossed into C57BL/6 for three to seven generations; $\mathrm{Kal} 7^{\mathrm{KO} /+}$ and $\mathrm{Kal} 7^{\mathrm{KO}}$ mice were compared with littermate controls. Screening of genomic DNA prepared from tail snips used primers A (AATAAAATTACTCAAGCCACTTCCAGTC), B (GGACATTTGCATGACATTGAGTCTAAAG), and E (TGTTCATACAGCTGTCTGGGG) (Fig. $1 B, C$ ). PCR conditions were as follows: $94^{\circ} \mathrm{C}, 2.5 \mathrm{~min} ; 55^{\circ} \mathrm{C}, 1 \mathrm{~min} ; 72^{\circ} \mathrm{C}, 32 \mathrm{~s}$; 40 cycles. Products encompassing the lox-p sites and the products of Flp and Cre recombinase were of the predicted sizes; DNA sequence analysis of excised bands confirmed their identities. The Kal7 ${ }^{\mathrm{CKO}}$ mice were created in the University of Connecticut Gene Targeting and Transgenic Facility.

\section{Antibodies used in these studies}

Antisera described previously include polyclonal antisera to the Kalirin spectrin domain (JH2582), Kal7 C-terminal end [affinitypurified JH2958; JH2959; specific for the C-terminal portion of the 20 aa residues unique to Kal7 (Ma et al., 2008)], Kal12 C-terminal end (JH3225), and monoclonal antibodies to the Kal7 C-terminal end (20D8; specific for the $\mathrm{N}$-terminal portion of the 20 aa residues unique to Kal7), PSD-95, and myc (Ma et al., 2008), and a polyclonal to Trio (CT233) (McPherson et al., 2005). Commercial antibodies to bassoon, Vglut1, GluR1, GluR2, NR1, GAD65, GAD65/67, vesicular GABA transporter (VGAT), MAP2, and green fluorescent protein (GFP) were as described previously (Ma et al., 2008). The following commercial antibodies were also used: synaptophysin (clone svp-38), $\delta$-catenin (C2989) and actin (A2066) (SigmaAldrich), NR2B (clone N59/20; NeuroMab), Shank3 (clone N69/46; NeuroMab), neuroligins-1 and -2 (Synaptic Systems), $\beta$ III-tubulin (Covance), glial fibrillary acidic protein (GFAP), CaMKII $\alpha$ (MAB3119), and Cre-recombinase (Millipore Bioscience Research Reagents), $\alpha$-adaptin, dynamin, and clathrin (BD Biosciences Transduction Laboratories), Ig binding protein (BiP) (Affinity BioReagents), Rac1 (23A8; Millipore), Cdk5, and PP1 (Santa Cruz Biotechnology).

Western blot analyses and Rac activation assays

For analysis of total protein, freshly dissected tissue or cells were sonicated in SDS lysis buffer and heated for $5 \mathrm{~min}$ at $95^{\circ} \mathrm{C}$ (Ma et al., 2008). Subcellular fractionation was used to prepare samples enriched in endoplasmic reticulum/Golgi, cytosol, synaptosomal membranes, synaptic vesicles, and synaptosomal cytosol (Huttner et al., 1983). Purified PSDs were prepared using a modification of published procedures (Carlin et al., 1980). PSDs removed from the interface of the 1.0/1.2 M sucrose layers of an equilibrium gradient were pelleted and then solubilized by incuba- 
tion for 30 min at $4^{\circ} \mathrm{C}$ with $0.5 \%$ Triton X-100 (TX-100), 10 mM HEPES, $\mathrm{pH}$ 7.4. The identity of various Kalirin proteins was established using differential antibody reactivity plus comigration with recombinant $\Delta \mathrm{Kal}$, Kal7, Kal9, and Kal12 (produced in pEAK-Rapid cells) (Schiller et al., 2008). $\Delta$ Kal7 expressed in insect cells using the baculovirus expression system was purified using Talon resin (Schiller et al., 2008). Protein concentrations were determined using bicinchoninic acid (Pierce) with bovine serum albumin as the standard.

For measurement of activated Rac, cerebral cortex (50 mg wet weight) was homogenized in $10 \mathrm{vol}$ of $10 \mathrm{~mm}$ HEPES, $320 \mathrm{~mm}$ sucrose, $10 \mathrm{~mm}$ $\mathrm{MgCl}_{2}, 1$ mM EDTA, 1 mм NaF, pH 7.4 containing $10 \mu \mathrm{g} / \mathrm{ml}$ GST-PakCRIB and protease inhibitor mix. After removal of debris $(1000 \times g$ for 5 $\min )$, Rac activation in the total lysate was assessed by adding $1 / 4 \mathrm{vol}$ of $5 \times$ MLB (125 mu HEPES, pH7.5, $750 \mathrm{~mm} \mathrm{NaCl}, 5 \%$ NP 40, $50 \mathrm{~mm} \mathrm{MgCl}_{2}, 5$ mu EDTA, 10\% glycerol) and allowing each sample to tumble with $15 \mu \mathrm{l}$ of glutathione Sepharose $4 \mathrm{~B}$ resin for $1 \mathrm{~h}$ at $4^{\circ} \mathrm{C}$. Beads were washed twice with $1 \times$ MLB containing $8 \%$ glycerol and bound proteins were eluted with boiling Laemmli sample buffer. Rac was visualized using monoclonal antibody from Millipore. Crude synaptosomes were prepared by differential centrifugation (Carlin et al., 1980); P2 was resuspended in $1 \times$ MLB containing $10 \mu \mathrm{g} / \mathrm{ml} \mathrm{GST}$-Pak-CRIB and allowed to tumble at $4^{\circ} \mathrm{C}$ for $20 \mathrm{~min}$ before centrifugation at $100,000 \times g$ for $15 \mathrm{~min}$; this supernatant was bound to glutathione Sepharose $4 \mathrm{~B}$ resin and washed as described above. Positive and negative controls were prepared as described previously (Xin et al., 2008).

\section{Immunocytochemistry}

Dissociated neurons. Immunocytochemical staining of neuronal cultures was performed as described previously (Ma et al., 2003, 2008). Neurons were generally fixed for $20 \mathrm{~min}$ in $4 \%$ paraformaldehyde in PBS or with anhydrous methanol $\left(-20^{\circ} \mathrm{C}\right)$. For visualization of synaptic proteins including PSD-95, NR1, Vglut1, GluR1, VGAT, and Kal7, cells were fixed with methanol for $12 \mathrm{~min}$ at $-20^{\circ} \mathrm{C}$, except where indicated. Primary antibodies were visualized with appropriate secondary antibodies as described previously (Ma et al., 2008).

Tissue sections. Immunohistochemical staining of tissue sections from perfusion-fixed mice has been described previously (Ma et al., 2001, 2002). Briefly, animals were perfused transcardially with $4 \%$ formaldehyde/0.1 M sodium phosphate buffer, $\mathrm{pH} 7.4$, under deep anesthesia with ketamine. After fixation, brains were postfixed in $4 \%$ paraformaldehyde for $6 \mathrm{~h}$. Sections $(10 \mu \mathrm{m})$ through dorsal hippocampus were cut using a cryostat and immunostained with appropriate antibodies as described previously (Ma et al., 2001).

\section{Golgi staining}

Animals were perfused transcardially with $2 \%$ formaldehyde/ $1 \%$ glutaraldehyde (in $0.1 \mathrm{~m}$ sodium phosphate buffer, $\mathrm{pH}$ 7.4) under deep anesthesia with ketamine $\left[n=4\right.$, wild type (Wt); $n=4$, Kal $\left.7^{\mathrm{KO}}\right]$. After fixation, brains were removed and half brains were placed in $4 \%$ paraformaldehyde overnight. Brains were then sectioned through dorsal hippocampus at $100 \mu \mathrm{m}$ on a vibratome and prepared for Golgi impregnation as described previously (Norrholm and Ouimet, 2000). The other half of each brain was processed for electron microscopy as described below.

\section{Electron microscopy}

The half brains prepared as described above were postfixed in $2 \%$ glutaraldehyde for $2 \mathrm{~h}$. Brains were then sectioned at $50 \mu \mathrm{m}$ on a vibratome and the sections were embedded in Polybed epoxy resin (Polysciences). Ultrathin sections $(50 \mathrm{~nm})$ from hippocampal CA1 stratum radiatum were cut with a Reichert Ultracut E ultramicrotome and collected on copper grids and counterstained with uranyl acetate and lead citrate. Sections were examined in a JEOL 100CX transmission electron microscope at $80 \mathrm{kV}$ accelerating voltage. For quantification of PSDs, images were taken at $8000 \times$ magnification. All measurements were performed independently by two researchers who were blind to the genotype of the animals.

\section{Behavioral and physiological testing}

Initial data. Animals were group housed in the University of Connecticut Health Center (UCHC) animal facility with a $12 \mathrm{~h}$ light/dark cycle (lights on 7:00 A.M. to 7:00 P.M.). All behavior experiments were done in accordance with UCHC Institutional Animal Care and Use Committee and National Institutes of Health procedures for animal care. Simple physiological observations were performed on all mice, including body weight over time and general observations such as lack of obvious tremor, normal gait, and ability to navigate/climb in the home cage. For behavioral studies, male littermates between 2 and 4 months of age were tested during the light phase. All animals were handled daily for at least $5 \mathrm{~d}$ before behavioral testing to minimize experimenter-induced stress during testing. With the exception of passive avoidance testing, all behavioral tests were performed in dim lighting in the Scoville Neurobehavioral Suite at UCHC. For all experiments, animals were allowed to habituate to the room for $1 \mathrm{~h}$ before testing. Some animals were reused for behavioral tests, but great care was taken to ensure that the less stressful tests preceded those that were more stressful (elevated zero $\rightarrow$ open field $\rightarrow$ object recognition $\rightarrow$ radial arm $\rightarrow$ passive avoidance). Statistical analysis was performed using SPSS software (SPSS) with one-way ANOVA or repeated-measures ANOVA to assess differences between groups.

Open field. Spontaneous locomotor activity was measured using a PAS Open Field system (San Diego Instruments). Briefly, animals were placed in the center of a 15 " $\times 15$ " Plexiglas chamber and their horizontal ambulatory activity was recorded by photocell beam breaks. Animals were allowed to move freely about the chamber for $1 \mathrm{~h}$ for a single testing session.

Elevated zero maze. The zero maze (San Diego Instruments) was made of white plastic with two "closed" quadrants consisting of 6 " tall walls on either side and two "open" quadrants with $1 / 4$ " walls. At the beginning of testing, each animal was placed in a closed quadrant facing it. Behavior was monitored by a blinded experienced scorer for the next $5 \mathrm{~min}$. Time spent in the open, open entries (all four paws entering the open arm), stretch attends (stretching of forepaws into the open arm before retraction into the closed arm), and head dips (dipping the head over the open arm to the crux of the mandible) were scored for each animal. Entry into a new quadrant was scored only when all four paws of the animal left the previous quadrant.

Passive avoidance. Mice were tested using a two compartment box with footshock grid (San Diego Instruments). On the training day, each animal was placed in the box with lights off and the interchamber door closed. After a $5 \mathrm{~s}$ habituation, the house lights were turned on only in the side where the mouse had been placed and the door was opened. When the mouse crossed to the darkened side, the door was closed and a 0.3 $\mathrm{mA} \times 2 \mathrm{~s}$ scrambled footshock was delivered. Mice were left in the shocked environment for $30 \mathrm{~s}$ before being returned to their home cage. For the test trial, animals were brought back to the room after the appropriate interval and run through the same protocol, but without footshock. For both training and testing, the latency to cross to the dark was measured using photocells in the boxes. Shock sensitivity was assessed (Hawasli et al., 2007) with cohorts of previously shocked and naive animals. Animals were placed in the box and given $2 \mathrm{~s}$ shocks ranging from 0.05 to $0.5 \mathrm{~mA}$. A blinded scorer examined videotape and recorded the lowest shock that elicited vocalization, flinching, and jumping.

Radial arm maze. The radial arm maze was used to test both working and reference memory. The maze (San Diego Instruments) consisted of a 5.25 " central platform with eight arms ( 2 " wide $\times 6$ " high) radiating from the platform. Extensive intramaze (distinct geometric shapes on walls) and extramaze (objects of varying shape and size present over arms) cues were provided throughout the testing procedures. Animals were food deprived for $5 \mathrm{~d}$ before the start of the experiment and were maintained at $85 \%$ of their free-feeding weight throughout training. Mice were first group habituated (three to four mice at a time) to the maze, in which reward pellets (small pieces of Cocoa Puffs cereal; General Mills) were scattered throughout. The mice were then given an individual habituation session with similarly scattered rewards. During testing, the animals were placed in the maze and confined to the center platform using a white cylinder for $15 \mathrm{~s}$. After the $15 \mathrm{~s}$ acclimation, the cylinder was removed and the animals were given free run of the maze. Throughout the training period, two arms separated by $135^{\circ}$ were baited with a hidden food pellet. The baited arms were varied between animals but remained consistent for each subject. Mice were allowed to explore the maze freely for $4 \mathrm{~min}$ 
or until both rewards were obtained. A blinded observer watched and scored throughout each session. Reference memory errors were scored when an animal entered an unbaited arm or when a baited arm was entered but the reward was not obtained. Working memory errors were reentries into arms within a trial. Two cohorts of animals were used for this experiment. In the first ( $4 \mathrm{Wt}$; $6 \mathrm{KO}$ ), animals were given one trial per day for the first $7 \mathrm{~d}$, and then three trials per day for the remaining days. Animals in the second cohort ( $5 \mathrm{Wt}$; $7 \mathrm{KO}$ ) were given two trials on the first day and three trials on each successive day. These differences in training procedure produced no difference in acquisition curves, so data were combined for the purpose of analysis.

Object recognition. Testing was performed in a large, clean cage normally used for housing rats. At the start of the training day, each mouse was placed into this novel environment, which contained no objects other than bedding, and allowed to habituate for $5 \mathrm{~min}$. After habituation, the animals were briefly placed in a holding cage while two identical objects were placed at either end of the cage $(50 \mathrm{ml}$ Falcon tubes or small Leggo objects). Mice were allowed $3 \mathrm{~min}$ to explore the two objects before being returned to their home cages. Twenty-four hours later, the animals were again habituated to the empty cage for $5 \mathrm{~min}$. When they were returned to the cage for the test, one of the objects was the same as the previous day (object A) and the other was a novel object (object B, the object not used previously). Animals were again allowed $3 \mathrm{~min}$ to explore the cage and objects. Both sessions were videotaped and scored by an experienced blinded observer. Object exploration was strictly defined as direct nasal contact with the object.

\section{Cell culture}

Hippocampal or cortical cultures from genotyped newborn mice [postnatal day 1 (P1)] were prepared as described previously (Ma et al., 2008); PCR genotyping allows same day culturing of $\mathrm{Wt}$ and $\mathrm{KO}$ neurons from $\mathrm{Kal} 7^{\mathrm{KO} /+} \times \mathrm{Kal} 7^{\mathrm{KO} /+}$ matings. Briefly, hippocampi or cortices were digested with $0.25 \%$ trypsin for $25 \mathrm{~min}$ at $37^{\circ} \mathrm{C}$. Dissociated cells were plated in Neurobasal A medium containing $7 \%$ heat-inactivated horse serum, maintained at $37^{\circ} \mathrm{C}$ in $5 \% \mathrm{CO}_{2}$. Three hours later, plating medium was replaced with fresh medium containing only $3 \%$ horse serum (heat inactivated), 2\% B27 supplement, $0.5 \mathrm{~mm}$ glutamine, $25 \mu \mathrm{M}$ glutamate, $25 \mathrm{U} / \mathrm{ml}$ penicillin, $25 \mu \mathrm{g} / \mathrm{ml}$ streptomycin. Three days after plating, the culture medium was exchanged with maintenance medium (Neurobasal A medium containing 2\% B27 supplement, $0.5 \mathrm{~mm}$ glutamine, $25 \mathrm{U} / \mathrm{ml}$ penicillin, $25 \mu \mathrm{g} / \mathrm{ml}$ streptomycin). Thereafter, one-half of the medium was replaced twice a week for up to 4 weeks. Nucleofection of freshly dissociated neurons was performed at P1 as described previously (Ma et al., 2008). Adenovirus encoding Cre recombinase (Iowa Gene Transfer Vector Core; http://www.uiowa.edu/ gene/) was used where indicated.

\section{Electrophysiological analysis of Kal7 null mice}

Slice preparation. Mice of 4-5 weeks of age were killed by decapitation and their brains were quickly removed in ice-cold artificial CSF (ACSF) solution containing the following (in $\mathrm{mm}$ ): $125 \mathrm{NaCl}, 26 \mathrm{NaHCO}_{3}, 10$ glucose, $2.3 \mathrm{KCl}, 2 \mathrm{CaCl}_{2}, 2 \mathrm{MgSO}_{4}, 1.26 \mathrm{KH}_{2} \mathrm{PO}_{4}$; aerated with $95 \% \mathrm{O}_{2}$ and $5 \% \mathrm{CO}_{2}, \mathrm{pH} 7.3,310 \mathrm{mOsm} / \mathrm{kg}$ (Zhou et al., 2008). Coronal slices, $300 \mu \mathrm{m}$ thick, were allowed to incubate at room temperature for at least $1 \mathrm{~h}$ before recordings.

Whole-cell recordings. Slices were transferred to a recording chamber heated to $32^{\circ} \mathrm{C}$ and perfused with aerated ACSF with the addition of 50 $\mu \mathrm{M}$ picrotoxin (PTX) (Sigma-Aldrich) to isolate excitatory neurotransmission. Recording pipettes with 3-5 $\mathrm{M} \Omega$ tips were filled with internal solution containing the following (in $\mathrm{mM}$ ): $135 \mathrm{~K}$-gluconate, $10 \mathrm{HEPES}$, 10 P-creatine, $3 \mathrm{Na}_{2} \mathrm{ATP}, 2 \mathrm{MgCl}_{2}, 0.3 \mathrm{Na}_{2} \mathrm{GTP}, \mathrm{pH} 7.3,285 \mathrm{mOsm} / \mathrm{kg}$ (Zhou et al., 2008). Cells were patched under visual guidance using infrared differential interference contrast optics. Data were collected using a Multiclamp 700B amplifier (Molecular Devices) and recorded/analyzed using pClamp 9.2 software (Molecular Devices).

Intrinsic membrane properties. Integrity of each patch was assessed through a series of negative and positive steps in current-clamp mode $(20 \times 100 \mathrm{pA}$ steps, -600 to $+1300 \mathrm{pA} ; 100 \mathrm{~ms}$ steps $)$. The three initial negative steps were used to calculate membrane resistance; single expo- nential curve fits yielded $\tau$ and capacitance. Action potential threshold was defined as the point of voltage inflection for the first spike fired in the lowest current step. Interspike interval was assessed in steps eliciting three or more spikes and defined as time between peaks of the last two spikes within a step.

Spontaneous glutamatergic activity. We recorded spontaneous EPSCs while voltage clamped at $-70 \mathrm{mV}$ for $1 \mathrm{~min}$ for each cell. Events observed in the full minute were analyzed using MiniAnalysis (Synaptosoft). Two outlier cells from each group were excluded from statistical analysis; their event frequency values were far more than 2 SDs above their group mean.

Long-term potentiation. Bipolar tungsten electrodes (World Precision Instruments) were placed in the stratum radiatum to stimulate Schaffer collateral axons. EPSCs were recorded in voltage-clamp mode at -70 $\mathrm{mV}$, with stimulation strength adjusted to obtain $20-50 \mathrm{pA}$ EPSCs at baseline. Test pulses were applied at $0.1 \mathrm{~Hz}$ to establish averaged baseline (10-25 pulses) and post-LTP induction EPSC values (25-50 pulses, recorded within $15 \mathrm{~min}$ after LTP induction). EPSC amplitudes were measured as the absolute difference between baseline and peak inward current within $50 \mathrm{~ms}$ after the stimulus artifact. A small subset of cells was recorded in the absence of PTX, and included in the analysis because their electrophysiological measures were consistent. LTP induction was initiated using theta burst pairing (TBP) in voltage-clamp mode and always within $15 \mathrm{~min}$ after achieving whole-cell configuration. LTP induction consisted of 15 four-pulse bursts at $100 \mathrm{~Hz}$ separated by $200 \mathrm{~ms}$ intervals, and each burst was paired with a $50 \mathrm{~ms}$ depolarizing voltage step to $0 \mathrm{mV}$. Cells that required $>200 \mu \mathrm{A}$ of stimulation or showed LTP $<120 \%$ were excluded from analyses (Kauer and Malenka, 2007). Statistical comparisons were made using Student's $t$ test.

\section{Image analysis and quantification}

Images captured using a Zeiss LSM510 Meta confocal microscope were analyzed as described previously (Ma et al., 2003, 2008). For quantification of spine density and synaptic clusters, a stack of images ( $Z$ step, 0.2 $\mu \mathrm{m})$ was acquired using a $63 \times$ objective $(3.0$ digital zoom factor $)$ and dendrites were visualized in three dimensions. For analysis of synaptic marker colocalization, single plane images through the brightest point were used. For analysis of Golgi staining, a stack of images ( $Z$ step, 0.2 $\mu \mathrm{m}$ ) was acquired using a Nikon TE 300 microscope with a $100 \times$ objective and a Hamamatsu camera; dendrites were visualized in three dimensions using Open Lab and Volocity software (Improvision). For each experiment, all images were taken with identical settings under the same conditions. Spine density and synaptic clusters were counted after images were calibrated and thresholds were set to ensure that all interesting structures were included in the analysis. Quantifications were performed using MetaMorph (Molecular Devices) and were limited to dendrites within $100 \mu \mathrm{m}$ of the soma in culture, or between 100-150 $\mu \mathrm{m}$ in tissue slices. Data are presented as average \pm SEM. Statistical analyses were performed with JMP6 software (SAS Institute) using one-way ANOVA followed by Dunnett's test or Student's $t$ test to assess statistical significance between groups; ${ }^{\star} p<0.05$ or ${ }^{\star *} p<0.01$ was considered statistically significant. All quantifications were performed independently by two investigators blind to genotype.

\section{Results}

\section{Design and characterization of Kal7 null $\left(\mathrm{Kal}^{\mathrm{KO}}\right)$ mice}

The targeting scheme shown in Figure 1 was used to establish two independent lines of mice with lox-p sequences flanking the single exon unique to Kal7 and $\Delta$ Kal7. The PCR schemes for screening mouse genomic DNA before and after Cre-recombinasemediated excision of the Kal7 exon are outlined in Figure $1 B-E$. Sequence analysis of the lox-p PCR product (primers A+B) and the knock-out allele PCR product (primers A $+E$ ) confirmed that lox-p insertion and DNA excision occurred as expected (data not shown). Neuronal cultures prepared from conditional null mice $\left(\mathrm{Kal} 7^{\mathrm{CKO} / \mathrm{CKO}}\right)$ were infected with adenovirus encoding Crerecombinase or GFP to verify successful excision of the Kal7 exon $($ Fig. $1 D)$. Male Kal7 ${ }^{+/ \mathrm{CKO}}$ mice were mated with female mice expressing Cre-recombinase, producing Kal7 ${ }^{+/ \mathrm{KO}}$ heterozygote 
mice, with a normal Kal7 allele from the mother and a null allele from the father (Fig. 1E). After several backcrosses into the $\mathrm{C} 57 \mathrm{BL} / 6$ background, $\mathrm{Kal} 7^{+/ \mathrm{KO}}$ heterozygote matings yielded wild-type, $\mathrm{Kal} 7^{+/ \mathrm{KO}}$, and $\mathrm{Kal}^{\mathrm{KO}}$ mice in the expected mendelian ratio with no differences in survival (Fig. $1 F$ ). Western analysis of cortical extracts from Kal7 ${ }^{\mathrm{KO}}$ mice demonstrated complete loss of Kal7 and $\Delta \mathrm{Kal} 7$ (Fig. 1G). Growth curves for wild-type and Kal7 ${ }^{\mathrm{KO}}$ mice were identical (Fig. $1 \mathrm{H}$ ).

\section{Hippocampal histology and spine density in adult male wild-type and Kal7 ${ }^{\mathrm{KO}}$ mice}

In Wt mice, Kal7 is at the postsynaptic side of virtually all excitatory synapses in the cortex and hippocampus (supplemental Fig. S1, available at www.jneurosci.org as supplemental material). Low-resolution images of the brain were obtained using cresyl violet-stained sections from wildtype and $\mathrm{Kal} 7^{\mathrm{KO}}$ mice (supplemental Fig. S2, available at www.jneurosci.org as supplemental material). The gross anatomy of the hippocampus and cortex, regions rich in $\mathrm{Kal} / \Delta \mathrm{Kal} 7$, and the cerebellum, a region with very little Kal7/ $\Delta \mathrm{Kal} 7$ (data not shown), did not differ between wild-type and $\mathrm{Kal} 7^{\mathrm{KO}}$ mice. To compare spine density and morphology, Golgi impregnation techniques were used, revealing a deficit in spine density along the apical dendrites of CA1 pyramidal neurons in $\mathrm{Kal} 7^{\mathrm{KO}}$ mice (Fig. $2 A, B$ ). In the $\mathrm{Kal}^{\mathrm{KO}}$ mice, linear spine density dropped to $85 \%$ of wild-type values (Fig. $2 C$ ); spines in the knock-out animals were smaller than those from wild-type animals (data not shown). Tissue sections from the hippocampus of wild-type and $\mathrm{Kal} 7^{\mathrm{KO}}$ mice of the same age were also examined immunocytochemically. Consistent with the decrease in spine density seen with the Golgi method, Kal7 ${ }^{\mathrm{KO}}$ tissue showed a slight decrease in Vglutl (excitatory presynaptic marker) and PSD-95 (postsynaptic marker) staining in the neuropil, with no change in GAD65 (inhibitory presynaptic marker) staining (data not shown).

\section{Normal gross development and physiology in Kal7 ${ }^{\mathrm{KO}}$ mice} From the time of birth, Kal7 ${ }^{\mathrm{KO}}$ mice exhibited no gross developmental or physiological deficits. Kal7 ${ }^{\mathrm{KO}}$ animals bred successfully with other Kal7 ${ }^{\mathrm{KO}}$ animals, with no difference in average litter size when compared with Wt pairs, and Kal7 ${ }^{\mathrm{KO}}$ pups suckled normally. Adult Kal7 ${ }^{\mathrm{KO}}$ animals had a normal gait, lacked any sign of tremor, had a normal righting reflex, had normal leg splay when lifted by the tail, and displayed normal climbing behavior in the home cage. In a wire hang test to measure grip strength, both wild-type and $\mathrm{Kal} 7{ }^{\mathrm{KO}}$ animals hung suspended from a wire for 3 min without failure. To measure their spontaneous locomotor activity, Wt, $\mathrm{Kal} 7^{\mathrm{KO} /+}$, and $\mathrm{Kal} 7^{\mathrm{KO}}$ mice were monitored for 60 min in an open field chamber. Genotype had no effect on total locomotor activity (supplemental Fig. S3, available at www. jneurosci.org as supplemental material). Additionally, mice of all three genotypes exhibited a similar decrease in locomotor activity across the $60 \mathrm{~min}$ session (data not shown).

\section{Decreased anxiety-like behaviors in $\mathrm{Kal} 7^{\mathrm{KO}}$ mice}

Given the apparent deficits in synaptic connectivity in $\mathrm{Kal} 7^{\mathrm{KO}}$ mice, baseline anxiety-like behavior was assessed to determine whether the morphological changes observed lead to behavioral changes (Pogorelov et al., 2005). Wild-type and Kal7 ${ }^{\mathrm{KO}}$ mice underwent a one-time elevated zero maze test. When compared with wild-type mice, $\mathrm{Kal}{ }^{\mathrm{KO}}$ mice spent significantly longer in the open arm of the elevated zero maze (Fig. $3 A$ ). Additionally, $\mathrm{Kal} 7{ }^{\mathrm{KO}}$ mice exhibited fewer stretch attend postures as they extended from the closed into the open area (Fig. $3 A$ ) and a greater number of open arm entries (data not shown). Data from the open field test (supplemental Fig. S3, available at www.jneurosci.org as supplemental material) demonstrated that these effects were not simply attributable to hyperactivity in response to a novel envi- 
A. Elevated Zero Maze

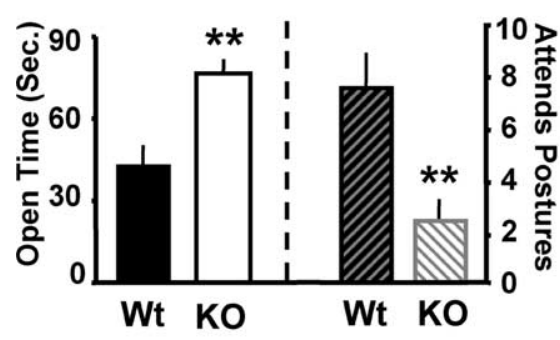

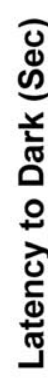

C. Radial Arm Maze

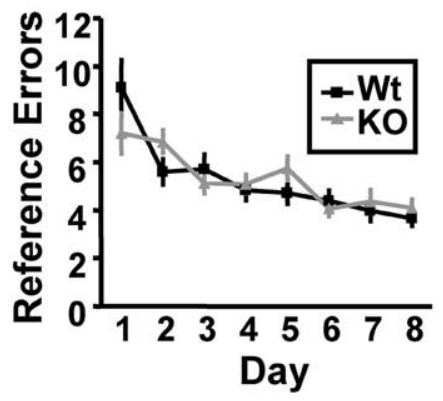

B. Passive Avoidance

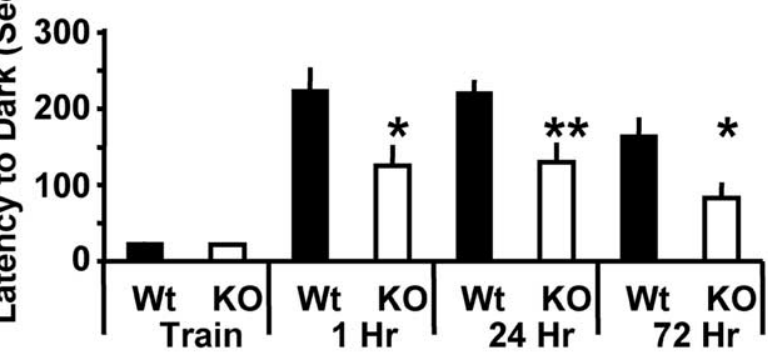

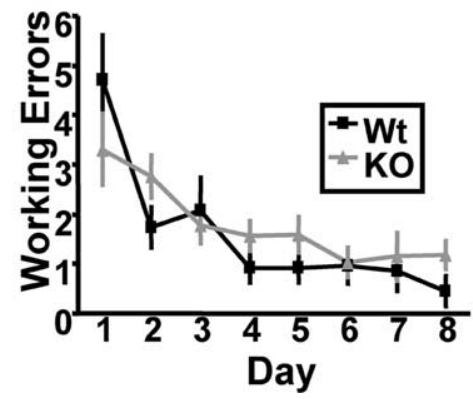

D. Object Recognition

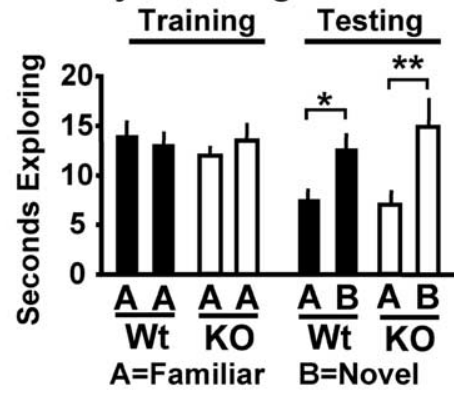

Figure 3. Behavioral deficits in Kal $7{ }^{\mathrm{K} 0}$ mice. $\boldsymbol{A}$, In the elevated zero maze, Kal7 ${ }^{\mathrm{K} 0}$ mice spent more time in the open arm ( $p=0.003$, AN0VA) and displayed fewer stretch attend postures ( $p=$ $0.011, \mathrm{ANOVA}$ ) ( $N=14 \mathrm{Wt} ; 9 \mathrm{KO})$ than Wt mice. $\boldsymbol{B}$, In a passive avoidance task, Kal7 ${ }^{\mathrm{KO}}$ and Wt mice exhibited no differences in training times $\left(p=0.895\right.$, ANOVA); compared with Wt mice, Kal $7{ }^{\mathrm{K} 0}$ mice showed decreased latency to enter the dark, shock-paired side at $1 \mathrm{~h}(p=0.03, \mathrm{ANOVA}), 24 \mathrm{~h}(p=0.006, \mathrm{ANOVA})$, and $72 \mathrm{~h}(p=0.02, \mathrm{ANOVA})$ after the training session. $\mathrm{C}$, In a radial arm maze acquisition task, both $\mathrm{Wt}(N=9)$ and $\mathrm{Kal} 7^{\mathrm{KO}}(\mathrm{N}=13)$ animals made an equal number of reference and working errors initially and throughout the learning sessions: left, reference errors, $F_{(1,20)}=0.02 ; p=0.888$, repeated-measures two-way ANOVA; right, working errors, $F_{(1,20)}=0.54 ; p=0.469$, repeated-measures tw0-way ANOVA. $D$, Both Wt $(N=11)$ and Kal7 ${ }^{\mathrm{KO}}(N=7)$ mice spent an equal amount of time exploring a novel object in an object recognition task ( $p=0.364$, Fisher's least significant difference); ${ }^{*} p<0.05$; ${ }^{* *} p<0.01$. Error bars indicate SEM.

ronment. Stretch attend postures are generally thought to represent hesitation as the mouse tries to avoid any unseen threat in the exposed area. The fact that the $\mathrm{Kal}^{\mathrm{KO}}$ mice made more open entries with fewer stretch attend postures indicates less anxiety about entering a potentially threatening area. Given the greater time spent in the open arms and the decreased hesitation to enter the open areas, it is clear that $\mathrm{Kal}^{\mathrm{KO}}$ mice have a significantly decreased level of anxiety-like behavior at baseline.

\section{Impaired contextual fear learning in $\mathrm{Kal}^{\mathrm{KO}}$ mice}

Passive avoidance conditioning was used to determine whether Kal7 ${ }^{\mathrm{KO}}$ mice exhibited altered abilities in a hippocampusdependent learning task; in this paradigm, lasting context-fear association can be imparted with a single training session ( $\mathrm{Du}-$ varci et al., 2005). During the training session, wild-type and $\mathrm{Kal}{ }^{\mathrm{KO}}$ animals showed the same latency to cross to the dark side of the chamber (Fig. 3B), whereupon they received a single footshock. When animals were tested $1 \mathrm{~h}$ after conditioning, Kal7 ${ }^{\mathrm{KO}}$ animals exhibited a significantly decreased latency to cross to the footshock-paired side. This decrease in latency was also seen in animals that were tested 24 and $72 \mathrm{~h}$ after conditioning. This pattern of behavior indicates that Kal ${ }^{\mathrm{KO}}$ animals had difficulty with the initial learning of the association rather than a simple deficit in long-term consolidation of the association. To ensure that the shock was being interpreted similarly by $\mathrm{Kal} 7^{\mathrm{KO}}$ and wild-type mice, a shock sensitivity test was performed. Both $\mathrm{Wt}$ and $\mathrm{Kal}{ }^{\mathrm{KO}}$ mice showed identical thresholds to vocalize, flinch, and jump in response to a scrambled footshock (supplemental Fig. S3, available at www.jneurosci.org as supplemental material). Together, these experiments indicate that Kal7 is necessary for contextual fear memory, which is dependent on both the hippocampus and amygdala (Paré et al., 2004).
Kal7 ${ }^{\mathrm{KO}}$ mice exhibit normal learning in a radial arm maze task as well as normal object recognition

From the passive avoidance experiments, it was clear that $\mathrm{Kal} 7{ }^{\mathrm{KO}}$ mice were deficient in learning in response to an aversive stimulus. We next examined their ability to acquire a repeated-trial appetitively motivated task that was also dependent on the hippocampus. For this task, $\mathrm{Kal}^{\mathrm{KO}}$ and wild-type mice were food deprived to $85 \%$ of their free-feeding body weight and trained to locate food rewards in a radial arm maze. By baiting only two arms, we were able to examine both long-term (reference) memory and short-term (working) memory. Each mouse received 23 trials in the maze and all mice decreased the number of reference and working memory errors made over the course of the training (effect of day, $F_{(1,20)}=13.65 ; p=0.001$, repeated-measures twoway ANOVA). The Kal7 ${ }^{\mathrm{KO}}$ mice made the same number of reference (Fig. 3C, left) and working (Fig. 3C, right) errors as the wild-type controls. Our experimental design allowed the animals free reign of the maze, likely leading to more exploratory reference errors, causing the number of errors to plateau at a higher level than reported with some other experimental designs (Bannerman et al., 2008; Hung et al., 2008). Regardless of this, animals of both genotypes showed significant improvement across days, with similar learning curves and similar final levels of responding. These data indicate that Kal7 is not necessary for this type of appetitive repeated-trial hippocampal conditioning.

To further test the ability of $\mathrm{Kal} 7^{\mathrm{KO}}$ animals to learn hippocampal-dependent tasks, an object recognition test was performed (Fig. 3D). There was no difference between genotypes in level of object exploration on the training day. Animals of each genotype showed significantly increased exploration of the novel object on day 2, and there was no significant difference between genotypes. These data indicate that $\mathrm{Kal} 7^{\mathrm{KO}}$ mice are able to form 
a stable contextual hippocampal dependent memory in a nonaversive context.

\section{Electrophysiological analysis of $\mathrm{Kal} 77^{\mathrm{KO}}$ mice}

To assess the functional consequences of Kal7 knock-out, we performed electrophysiological recordings from acute slice preparations. First, we evaluated passive membrane properties. Capacitance is a measure of cell surface area and dendritic spines contribute $40-70 \%$ of the total surface area of hippocampal CA1 pyramidal cells (Harris and Stevens, 1989; Mainen et al., 1996; Inoue et al., 2001). Given the reduction in spine density observed in the CA1 pyramidal neurons of Kal7 ${ }^{\mathrm{KO}}$ mice (Fig. 2), we expected to see slightly reduced capacitance values for Kal $7{ }^{\mathrm{KO}}$ versus Wt neurons. Hyperpolarizing and depolarizing current steps were applied to patched CA1 hippocampal neurons to provide measures of membrane resistance and $\tau$ so that capacitance could be calculated (Fig. 4A). On average, $\mathrm{Kal}^{\mathrm{KO}}$ neurons had higher input resistance (Wt, $122 \pm 7 \mathrm{M} \Omega$; Kal7 ${ }^{\mathrm{KO}}, 147 \pm 5 \mathrm{M} \Omega ; p=$ 0.008 ; $32 \mathrm{Wt}$ neurons and $29 \mathrm{Kal}^{\mathrm{KO}}$ neurons) and lower membrane capacitance (Wt, $66 \pm 3 \mathrm{pF} ; \mathrm{Kal} 7{ }^{\mathrm{KO}}, 57 \pm 2 \mathrm{pF} ; p=0.028$ ); time constants did not differ $\left(\mathrm{Wt}, 7.6 \pm 0.3 \mathrm{~ms} ; \mathrm{Kal} 7^{\mathrm{KO}}, 8.1 \pm 0.3\right.$ $\mathrm{ms} ; p=0.19)$. The resting potential and action potential threshold for knock-out and Wt pyramidal neurons were identical (supplemental Fig. S4A, available at www.jneurosci.org as supplemental material). In knock-out neurons, the number of action potentials fired during weak depolarizing current steps was slightly increased (supplemental Fig. $\$ 4 B$, available at www. jneurosci.org as supplemental material), whereas latency to fire the first action potential after step initiation was decreased (supplemental Fig. S4C, available at www.jneurosci.org as supplemental material); both results are consistent with the decreased membrane capacitance (decreased surface area) observed in $\mathrm{Kal}{ }^{\mathrm{KO}}$ neurons. There was no significant difference in interspike interval between the two groups. Because the CA1 pyramidal neurons of Kal ${ }^{\mathrm{KO}}$ mice have fewer dendritic spines, we assessed spontaneous EPSCs (Fig. 4B); as predicted, spontaneous EPSC frequency was significantly decreased in Kal $7^{\mathrm{KO}}$ neurons. No difference was observed in amplitude (supplemental Fig. $S 4 D$, available at www.jneurosci.org as supplemental material).

We went on to compare plastic properties of Wt and $\mathrm{Kal}^{\mathrm{KO}}$ synapses. EPSCs, evoked via Schaffer collateral stimulation, were of similar amplitude and required similar stimulation strengths in Wt and $\mathrm{Kal}^{\mathrm{KO}}$ neurons (supplemental Fig. S4 E, F, available at www.jneurosci.org as supplemental material). Taken with the lack of difference in spontaneous EPSC amplitude, these data suggest normal strength of basal synaptic transmission in Kal7 ${ }^{\mathrm{KO}}$ neurons. To measure LTP, EPSCs were examined before and after applying a TBP paradigm. A single TBP trial resulted in significant LTP that was maintained for at least $1 \mathrm{~h}$ in both $\mathrm{Wt}$ and $\mathrm{Kal}{ }^{\mathrm{KO}}$ slices (Fig. 4C). LTP was quantified by comparing EPSC amplitudes within 15 min after the TBP trial to averaged baseline EPSC amplitudes. Compared with Wt neurons, Kal $7^{\mathrm{KO}}$ neurons showed markedly blunted LTP (Fig. 4B,C). This deficiency in LTP may correlate with the decreased ability to acquire behavioral training (Fig. 3), because LTP is typically considered to be one cellular correlate of learning.

Kal7 and $\Delta \mathrm{Kal} 7$ are reduced to one-half in $\mathrm{Kal} 7^{+/ \mathrm{KO}}$ mice and eliminated in $\mathrm{Kal} 7{ }^{\mathrm{KO}}$ mice

Antisera specific for the sequence encoded by the Kal7 exon were used to evaluate the success of the targeting strategy (Fig. 5A). In both cortex and hippocampus, levels of Kal7 and $\Delta \mathrm{Kal} 7$ were reduced to $\sim 50 \%$ of $\mathrm{Wt}$ levels in $\mathrm{Kal}^{+/ \mathrm{KO}}$ mice (Fig. $5 B$ ); no
A.
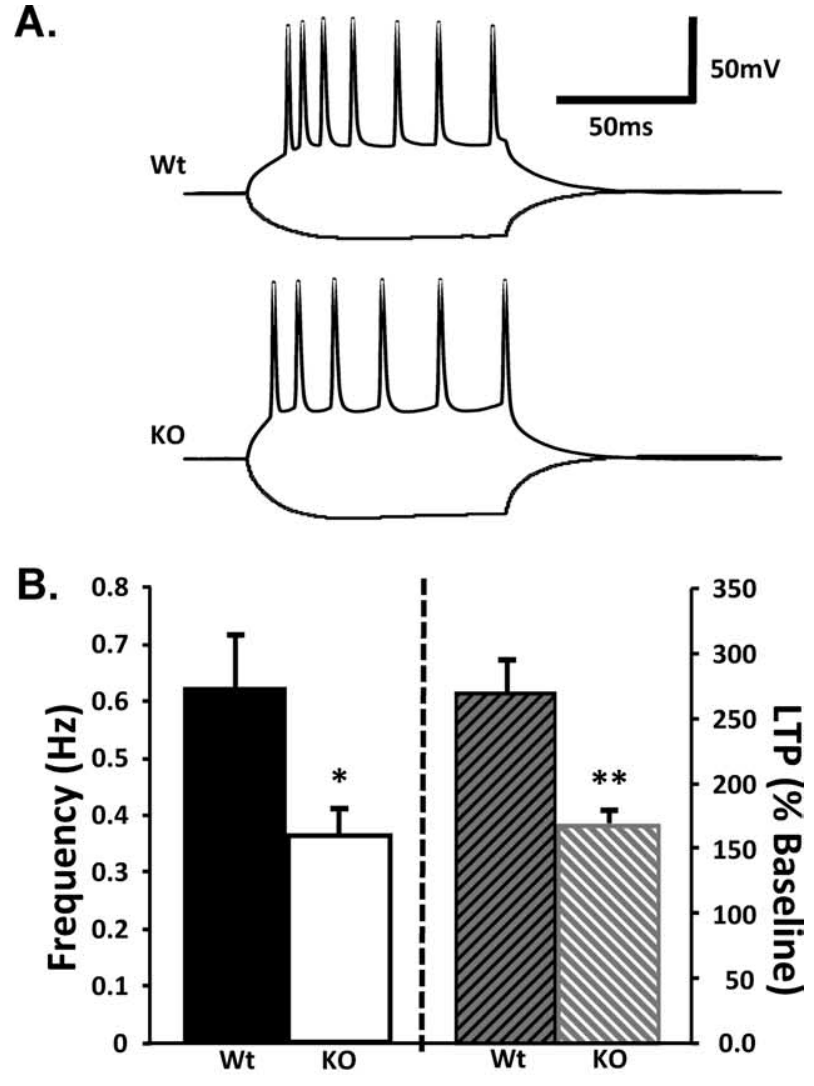

C.
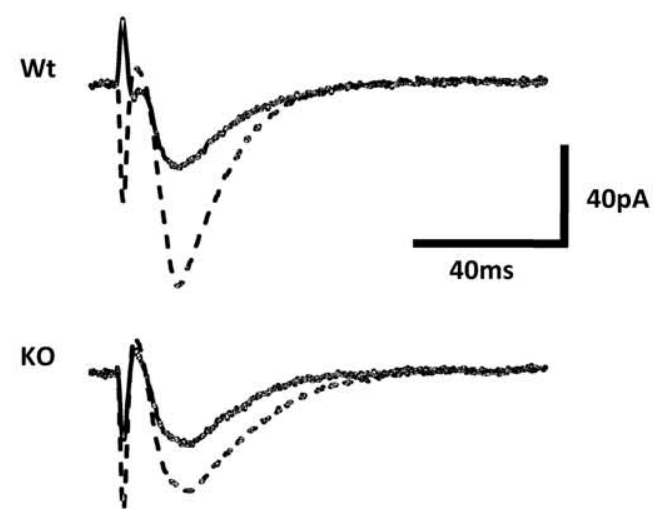

Figure 4. Electrophysiological deficits. $A$, Representative traces from Wt and Kal7 ${ }^{\mathrm{KO}} \mathrm{CA} 1$ pyramidal neurons of membrane responses to positive and negative $200 \mathrm{pA}$ somatic current injections. $B$, Composite spontaneous EPSC frequency $(N=24 \mathrm{Wt}$, $18 \mathrm{KO}$ neurons; $p=0.023$; left) and LTP ( $N=7 \mathrm{Wt}, 13 \mathrm{KO}$ neurons; $p=0.0079$; right) data. Error bars indicate SEM. $C$, Averaged traces of EPSCS recorded from single CA1 pyramidal neurons from Wt and Kal $7{ }^{\mathrm{K} 0}$ mice before and within 15 min after theta burst pairing.

compensatory increase in Kal7 expression was observed. In the $\mathrm{Kal}{ }^{\mathrm{KO}}$ mice, cross-reactive material the size of Kal7 and $\Delta \mathrm{Kal} 7$ was eliminated (Fig. 5A). Differential centrifugation was used to prepare fractions enriched in synaptsomal membranes (LP1), synaptic vesicles (LP2), synaptosomal cytosol (LS2), endoplasmic reticulum/Golgi (P3), and cytosol (S3). Two independent polyclonal antisera specific for the $\mathrm{C}$ terminus of Kal7/ $\Delta \mathrm{Kal} 7 \mathrm{con}$ firmed its elimination in the Kal7 ${ }^{\mathrm{KO}}$ mice (Fig. $5 C$ ) (one shown).

Transcripts encoding Kal9 and Kal12 are generated by splicing Kalirin exon 33 to exon 34, eliminating the exon that encodes the unique $\mathrm{C}$ terminus and 3 '-untranslated region of Kal7 (McPherson et al., 2002) (Fig. 5D). The genomic region excised in the Kal7 ${ }^{\mathrm{KO}}$ 

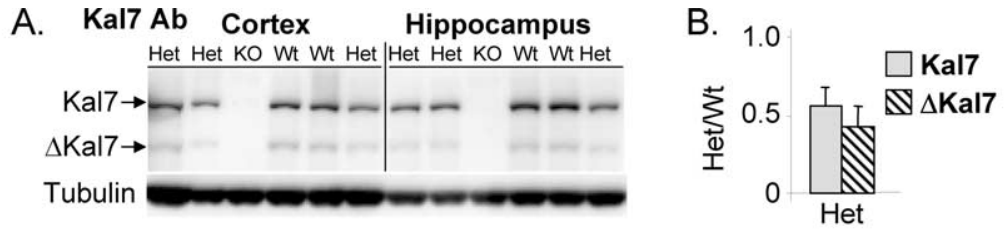

\section{Affinity-purified Kal7Ab $\begin{array}{lllll}\text { LP1 } & \text { LP2 } & \text { LS2 } & \text { P3 } & \text { S3 }\end{array}$ Wt KO Wt KO Wt KO WtKO Wt KO}

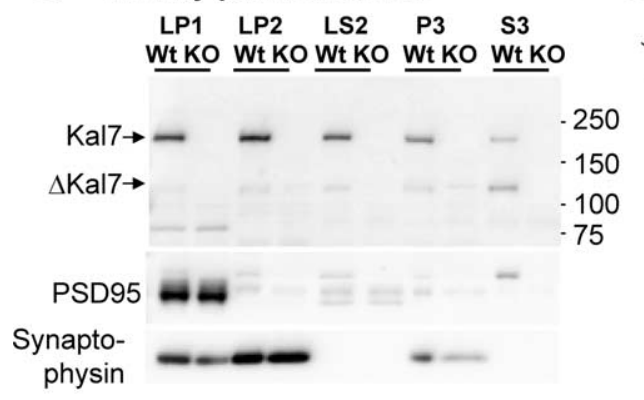

D. mRNA splicing around Kal7 exon

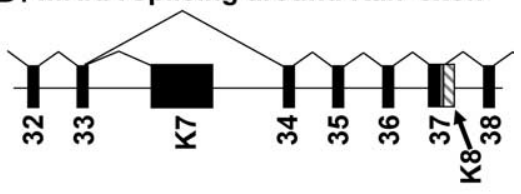

E. PanKal Ab

Wt KO Wt KO
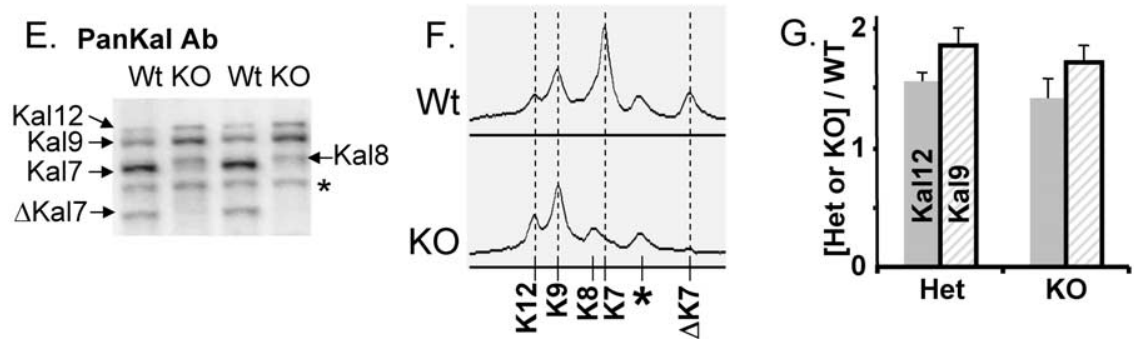

Figure 5. Biochemical verification of Kal $7^{\mathrm{K} 0}$. A , Total SDS lysates (20 $\mu \mathrm{g}$ protein) prepared from the parietal cortices and hippocampi of Wt, Het, and Kal7 ${ }^{\mathrm{Ko}}$ mice were analyzed for Kal7 and $\beta$ III-tubulin. $\boldsymbol{B}$, Levels of $\mathrm{Kal} 7$ and $\Delta \mathrm{Kal} 7$ in Kal $7^{+/ \mathrm{Ko}}$ mice were compared with levels in Wt mice. C, Parietal cortices from Wt and Kal7 ${ }^{\mathrm{K} 0}$ mice were separated into crude subcellular fractions. Equal amounts of protein $(5 \mu \mathrm{g})$ from each fraction were analyzed using Kal7-specific antibody (JH2959); similar results were obtained with affinity-purified Kal7-specific antibody (JH2958). The success of the fractionation was verified by visualizing synaptophysin and PSD-95. D, The splicing pattern for the region around the Kal7-specific exon is depicted; introns are not drawn to scale. Kal8 transcripts retain part of the adjacent intron (hatched), including a small protein coding region (gray) followed by a poly(A) addition signal and a poly(A) tract (Johnson et al., 2000). E, SDS lysates $(20 \mu \mathrm{g})$ prepared from parietal cortices of Wt and $\mathrm{Kal} 7{ }^{\mathrm{K} 0}$ mice were visualized with a pan-Kalirin antibody, JH2582; the asterisk indicates a nonspecific band. $\boldsymbol{F}$, Scans of gels were aligned, revealing the presence of Kal8 in Kal7 ${ }^{\mathrm{K} 0}$ lysates; the asterisk indicates a nonspecific band. G, Levels of Kal12 and Kal9 in Het and KO mice were compared with Wt mice $(n=7)$. Error bars indicate SEM.

mouse included the poly(A) addition site (McPherson et al., 2002). To explore the possibility that transcripts that would normally encode Kal7 generated Kal8, Kal9, and Kal12 in Kal7 ${ }^{\mathrm{KO}}$ mice, we used pan-Kalirin antibodies to visualize these isoforms (Fig. 5E). As expected, neither Kal7 nor $\Delta \mathrm{Kal} 7$ were detectable in $\mathrm{Kal}{ }^{\mathrm{KO}}$ mice, but levels of Kal9 and Kal12 increased. Scans of these gels confirmed the appearance of a protein the size of Kal8 (Fig. $5 F$ ) and quantification revealed an increase of $\sim 50 \%$ in levels of Kal9 and Kal12 in both

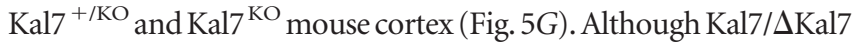
account for $\sim 75 \%$ of the pan-Kalirin signal in wild-type samples, the increased levels of Kal8, Kal9, and Kal12 in Kal $7^{\mathrm{KO}}$ cortex mean that pan-Kalirin levels normalized to tubulin dropped by only $\sim 25 \%$ in the knock-outs (to $74 \pm 5 \%$ of wild-type; $N=7$ ).

Biochemical analysis of $\mathrm{Kal} 7^{\mathrm{KO}}$ mice

We first examined levels of cell type-specific markers in SDS lysates prepared from cerebral cortex. Neuron-specific BIIItubulin, GAD (glutamic acid decarboxylase) (a marker for inhibitory neurons), and GFAP (a marker for astrocytes) were unaltered (Fig. $6 \mathrm{~A}$ ). Proteins abundant in presynaptic terminals (synaptophysin, $\alpha$-adaptin, and clathrin) were unchanged, as was $\mathrm{BiP}$, a major endoplasmic reticulum marker common to all cells. Levels of known Kalirin interactors were then assessed (Fig. 6B); levels of PSD-95, a Kal7/DKal7-specific interactor (Penzes et al., 2001), and Rac1, a Kal7 substrate, were unaltered. Cdk5, which phosphorylates $\mathrm{Thr}^{1590}$ in Kal7/ $\Delta \mathrm{Kal}$, and PP1, which reverses this modification (Xin et al., 2008), were unaltered. Levels of dynamin, an interactor with the IgFnIII domain of Kalirin (X. Xin, C. A. Rabiner, R. E. Maingess, B. A. Eipper, unpublished observations) were unaltered. Levels of several postsynaptic proteins, AMPA receptor subunits GluR1 and GluR2, and NMDA receptor subunits NR1 and NR2B were unaltered in $\mathrm{Kal} 7{ }^{\mathrm{KO}}$ mice (Fig. 6C); levels of neuroligin-1, another component of the PSD, were unaltered. Finding normal levels of these markers in tissue lysates is consistent with the limited deficits observed. The significant alterations observed in Golgi impregnation profiles (Fig. 2), behavioral parameters (Fig. 3), and electrophysiological properties (Fig. 4) led us to focus on the ultrastructure of synapses in $\mathrm{Kal} 7{ }^{\mathrm{KO}}$ versus $\mathrm{Wt}$ mice.

\section{Hippocampal ultrastructure in adult} male $\mathrm{Wt}$ and $\mathrm{Kal} 7^{\mathrm{KO}}$ mice

Synapses on the apical dendrites of CA1 hippocampal pyramidal neurons in $\mathrm{Wt}$ and $\mathrm{Kal} 7^{\mathrm{KO}}$ neurons were compared (Fig. $7 A, B)$. Despite the total absence of Kal7, synaptic structures of normal appearance were plentiful in Kal $7{ }^{\mathrm{KO}}$ tissue. Postsynaptic densities aligned with presynaptic endings full of small synaptic vesicles were prevalent in $\mathrm{Wt}$ and $\mathrm{Kal}^{\mathrm{KO}}$ tissue. The formation of spines is clearly possible in the total absence of Kal7. The length and thickness of the PSD were measured in wild-type and $\mathrm{Kal}{ }^{\mathrm{KO}}$ neurons (Fig. 7C,D). Compared with wildtype mice, there was a small, but significant decrease in both the length and thickness of the PSD in Kal7 ${ }^{\mathrm{KO}}$ mice (Fig. $\left.7 C, D\right)(p<$ 0.005 , Kolmogorov-Smirnov; $800+$ PSDs measured for each plot). Even a change of this magnitude can be of significance in synaptic transmission (Harris and Stevens, 1989; Hung et al., 2008). The synapses present in micrographs from the CA1 region of wild-type and Kal7 ${ }^{\mathrm{KO}}$ tissue were counted (Fig. $7 A, B$, arrows). The number of synapses (defined as a PSD with apposed presynaptic ending containing vesicles) in Kal7 ${ }^{\mathrm{KO}}$ mice dropped by about one-third compared with wild-type mice (from $0.53 \pm$ $0.02 / \mu \mathrm{m}^{2}$ to $0.31 \pm 0.02 / \mu \mathrm{m}^{2}$; synapses in $100 \mu \mathrm{m}^{2}$ were quantified for five images of each genotype; $p<0.005$, Student's $t$ test). Although larger in magnitude, the change in ultrastructurally identified synapse number is consistent with the decrease in linear spine density observed using Golgi impregnation (Fig. 2). Our cell culture studies demonstrated that Kal7 short hairpin RNA (shRNA) and antisense treatments produced spine-like structures lacking presynaptic terminals; if a similar phenomenon occurs in vivo, synapse number as measured by EM would decrease more than spine number as measured by Golgi staining (Ma et al., 2003, 2008). 
Biochemical characterization of purified PSDs from Kal7 ${ }^{\mathrm{KO}}$ mice

Although the GEF domain of Kal7 clearly has a catalytic role, its spectrin-repeat region suggests that Kalirin might serve a structural role similar to that of spectrin itself (Schiller et al., 2008). To evaluate this possibility, we determined the average number of Kal7 molecules present per PSD (Fig. $8 A$ ). The PSD purification protocol optimized for wild-type mouse cortex and hippocampus worked well for tissue from Kal7 ${ }^{\mathrm{KO}}$ mice (supplemental Fig. S5, available at www.jneurosci.org as supplemental material). Using purified $\Delta \mathrm{Kal} 7$ as a standard, we determined that the average cortical or hippocampal PSD contained only 9-12 molecules of Kal7. With hundreds of copies of PSD-95, Shank, and Homer per PSD, a structural role for Kal7 seems unlikely (Sugiyama et al., 2005; Béïque et al., 2006; Cheng et al., 2006; Collins et al., 2006; Elias et al., 2006; Sheng and Hoogenraad, 2007).

A pan-Kalirin antibody was used to compare the Kalirin content of PSDs purified from wild-type and $\mathrm{Kal} 7^{\mathrm{KO}}$ animals (Fig. $8 \mathrm{~B}$ ). Although Kal7 was absent, the amount of Kal9 and Kal12 in Kal7 ${ }^{\mathrm{KO}}$ PSDs increased compared with Wt PSDs (up $50 \pm 22$ and $79 \pm 21 \%$ over wild-type, respectively), indicating that the $\mathrm{PDZ}$ binding motif at the $\mathrm{C}$ terminus of Kal7 is not the only means of localizing Kalirin to the PSD. In non-neuronal cells, both Sec14p mediated interactions with phosphatidylinositides and the spectrin-repeat region contribute to the association of Kal7 with membranes (Schiller et al., 2008). To determine whether the absence of Kal7 diminished Rac activation, we assayed crude tissue homogenates and the synaptosomal fraction (P2) for Rac1-GTP using the Pak-CRIB pulldown assay (Schiller et al., 2008). No difference in Racl activation was detected in either fraction under baseline conditions (supplemental Fig. S5C, available at www.jneurosci.org as supplemental material). Investigation of specific signaling pathways may be required to reveal the effect of a lack of Kal7 on Rac activation.

Because $\mathrm{Kal} 7^{\mathrm{KO}}$ neurons were deficient in LTP, we examined levels of AMPA receptor subunits GluR1 and GluR2 and NMDA receptor subunits NR1 and NR2B in purified cortical PSDs (Fig. 8C). A significant decrease in the level of NR2B was observed, with no significant change in GluR1, GluR2, or NR1 (Fig. 8D). Levels of neuroligin-2, which is associated with inhibitory synapses (Varoqueaux et al., 2006; Chubykin et al., 2007), and $\delta$-catenin, a neuronspecific catenin that binds synaptic scaffolding proteins and affects AMPA receptor trafficking (Kosik et al., 2005; Ochiishi et al., 2008), were unchanged. Additional studies will be required to determine whether surface levels of AMPA and NMDA receptors and receptor trafficking are altered.

We next looked at levels of several Kal7 interactors. Neither levels of CaMKII $\alpha$, which has been reported to phosphorylate Kalirin (Xie et al., 2007), nor actin were changed (Fig. 8C). Levels of PSD-95, which binds the C terminus of Kal7, and Rac1, a Kalirin substrate, were unaltered (Fig. 8C). The most striking change observed was a decrease in the level of Cdk5 (Fig. 8C,D), which phosphorylates Kal7 at $\mathrm{Thr}^{1590}$ (Xin et al., 2008). Because Cdk5 associates with membranes via its interactions with $\mathrm{p} 35$ and p39, we examined Cdk5 levels in the TX-100 wash used to prepare PSDs; levels of Cdk5 were also reduced in this fraction (Fig. $8 C, D)$. Cdk5 regulates the actions of a wide variety of postsynaptic proteins (Morabito et al., 2004; Hawasli et al., 2007; Zhang et al., 2008) and its loss may contribute to the phenotype observed in $\mathrm{Kal} 7^{\mathrm{KO}}$ mice. Levels of PP1, which dephosphorylates P-Thr ${ }^{1590}$ of Kal7 (Xin et al., 2008), were unchanged.

The late stages of synaptogenesis are deficient in $\mathrm{Kal} 7^{\mathrm{KO}}$ neurons in culture

We next asked whether the differences in spine density seen in $\mathrm{Kal} 7^{\mathrm{KO}}$ mice in vivo could be reproduced in vitro. Dissociated cortical neurons prepared from P1 wild-type and Kal7 ${ }^{\mathrm{KO}}$ littermates were examined after 7, 14, 21, or $28 \mathrm{~d}$ in vitro (DIV) (Fig. 9; supplemental Fig. S6, available at www.jneurosci.org as supplemental material). At each time point, replicate cultures were stained for MAP2, a dendritic marker, and Vglut1; one culture 

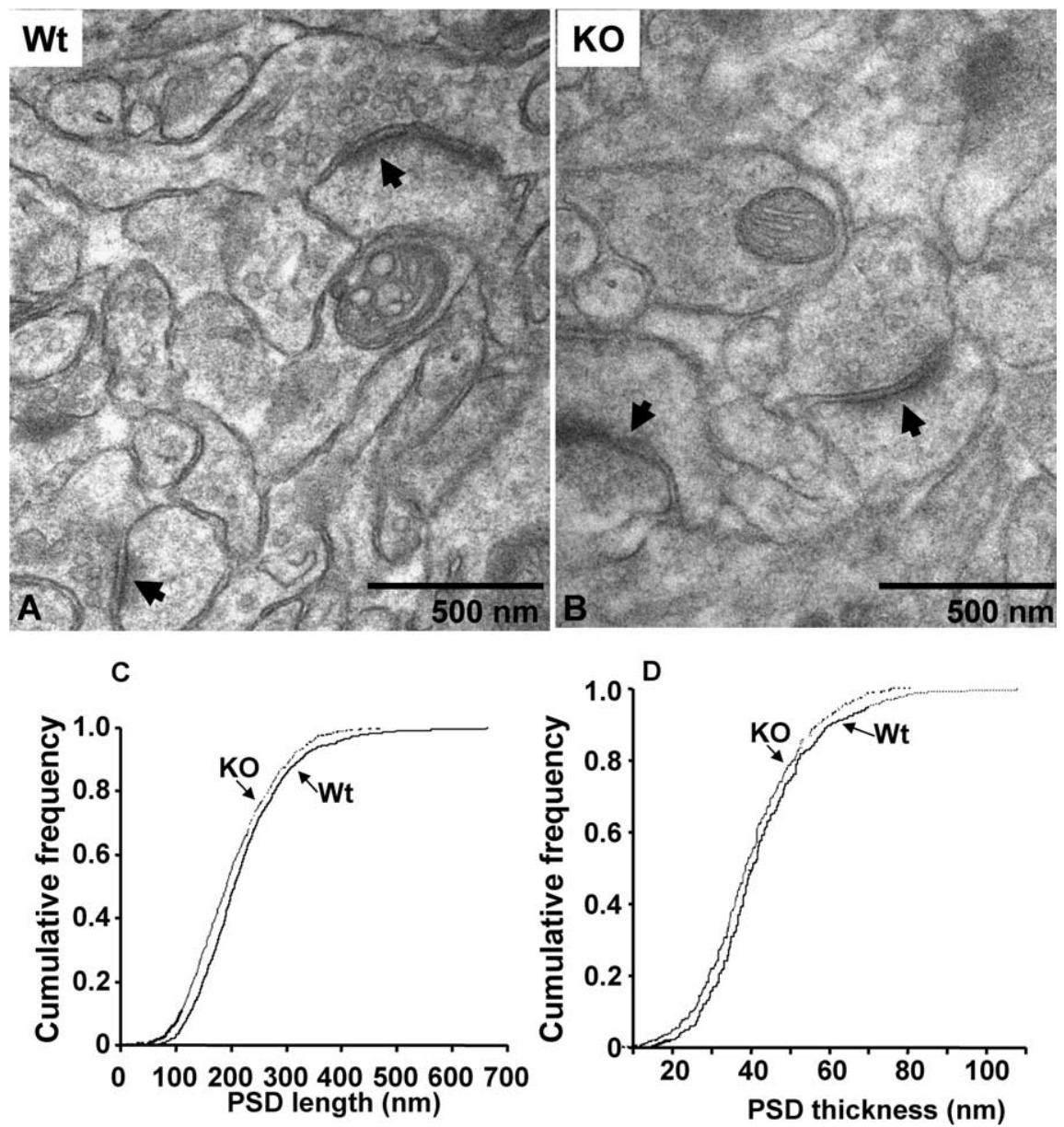

Figure 7. Normal synapses are formed in Kal $7{ }^{\mathrm{K} 0}$ mice. $\boldsymbol{A}$, Representative electron micrographs of hippocampal CA1 striatum radiatum synapses from adult Wt and Kal $7{ }^{\mathrm{K} 0}$ mice. Complete synapses (PSDs apposed to presynaptic endings with vesicles) were readily identified in $\mathrm{Kal} 7^{\mathrm{K} 0}$ tissue. PSD length and thickness were measured. Cumulative frequency distributions of PSD length (C) and thickness $(\boldsymbol{D})$ from Wt (solid line) and Kal7 ${ }^{\mathrm{K} 0}$ (dashed line) mice are shown. Both PSD length $(\boldsymbol{C}$ ) and thickness (D) were decreased in Kal7 ${ }^{\mathrm{KO}}$ mice. At least 800 randomly selected synapses from each of four Wt and four Kal7 ${ }^{\mathrm{KO}}$ mice were measured by observers blind to genotype. Differences are significant by Kolmogorov-Smirnov ( $p<0.005)$.

was stained for Kal7 and the other for PSD-95. Images from DIV28 are shown in Figure 9, and images from DIV7 and DIV14 are shown in supplemental Figure S6 (available at www. jneurosci.org as supplemental material). The MAP2 staining patterns were similar in wild-type and $\mathrm{Kal}^{\mathrm{KO}}$ neurons at all time points, but dendritic morphology has not yet been quantified. As expected, Kal $7^{\mathrm{KO}}$ cultures lacked any detectable staining for Kal7 at all time points. At DIV28, Vglut1 staining along wild-type dendrites was almost perfectly aligned with Kal7 staining (Fig. 9A). Vglut1-positive clusters still abutted the dendritic shafts of Kal7 ${ }^{\mathrm{KO}}$ neurons (Fig. 9B,C). Quantification revealed a decrease of $28 \%$ in the density of Vglut 1 positive clusters along the dendrites of DIV28 Kal7 ${ }^{\mathrm{KO}}$ neurons (Fig. 9G,H). Vglut1 staining was paired with PSD-95 to determine whether glutamatergic presynaptic endings were contacting dendritic spines (Fig. 9D-F). In DIV28 wild-type neurons, almost every Vglut1 cluster was apposed to a PSD-95-positive cluster. The number of Vglut1PSD-95 clusters along the dendrites of $\mathrm{Kal} 7{ }^{\mathrm{KO}}$ neurons dropped by $39 \%$ and Vglut 1 clusters not apposed to PSD-95 clusters became apparent (Fig. 9 E, F,H $)\left(0.99\right.$ Vglut alone $/ 10 \mu \mathrm{m}$ in $\mathrm{Kal}^{\mathrm{KO}}$; $p=0.003$ vs Wt; green stars). These data are in remarkably good agreement with the decrease in the number of synapses in vivo in the ultrastructural analyses (Fig. 7).
Younger cultures were examined to determine when these differences between $\mathrm{Kal}{ }^{\mathrm{KO}}$ and wild-type neurons became apparent (supplemental Fig. S6, available at www.jneurosci.org as supplemental material). Similar numbers of Vglut1-PSD-95 clusters were found along the dendrites of wild-type and $\mathrm{Kal}^{\mathrm{KO}}$ neurons at DIV7; Kal7 was not yet detectable in wild-type neurons (supplemental Fig. S6 A, available at www.jneurosci.org as supplemental material). For both wild-type and $\mathrm{Kal} 7{ }^{\mathrm{KO}}$ neurons, the number of dendritic Vglutl clusters increased substantially by DIV14 (supplemental Fig. S6B,C, available at www.jneurosci.org as supplemental material). In wild-type neurons, Kal7 staining localized to the postsynaptic side of a few Vglut1-positive synapses. As at DIV7, neither the number of Vglut1 clusters nor the number of Vglut1-PSD-95 clusters was altered in Kal7 ${ }^{\mathrm{KO}}$ neurons (supplemental Fig. S6C, available at www.jneurosci.org as supplemental material). At DIV21, Kal7 was detected in most excitatory synapses in wild-type cultures. However, $\mathrm{Kal} 7^{\mathrm{KO}}$ neurons and wild-type neurons still had the same number of Vglut1 clusters and Vglut1-PSD-95 synapses (supplemental Fig. S6C, available at www.jneurosci.org as supplemental material). The linear density of Vglut1 clusters along the dendrites of $\mathrm{Kal}{ }^{\mathrm{KO}}$ neurons did not increase after DIV14 (Fig. 9G), whereas wild-type neurons formed more synapses between DIV14 and DIV28 ( $p=0.032$, Wt vs KO at DIV28).

\section{Rescue of Kal7 ${ }^{\mathrm{KO}}$ neurons}

We next asked whether the deficit in dendritic spines observed in Kal7 ${ }^{\mathrm{KO}}$ neurons could be reversed by introduction of exogenous Kal7. DIV1 cortical neurons from $\mathrm{Kal}{ }^{\mathrm{KO}}$ mice were transfected with two different amounts of vector encoding Kal7; control neurons were not transfected (Fig. 10). At DIV28, expression of Kal7 caused a DNA dose-dependent increase in the number of Vglut1-positive clusters along the dendrites of Kal7 ${ }^{\mathrm{KO}}$ neurons (Fig. $10 B-D$ ). The presynaptic Vglut1 terminals were closely aligned with postsynaptic clusters of Kal7 (Fig. 10B,C). The Vglut1 clusters were aligned with PSD-95-, NR1-, and GluR1-positive clusters (data not shown).

\section{Discussion}

Kal7 plays an essential role in neuronal function in vivo

A series of in vitro studies demonstrated that Kal7 is necessary for the formation and maintenance of dendritic spines (Ma et al., 2003, 2008). We show here that mice lacking Kal7 have deficits severe enough to affect synaptic transmission and specific behaviors. Shank1 and Kal7 are essential for dendritic spine formation in vivo and in culture, but $\mathrm{Kal}{ }^{\mathrm{KO}}$ produces a greater drop in hippocampal spine density than Shank1 (15 vs 6\%) (Hung et al., 2008), making Kal7 an important model for human disease. Mental retardation syndromes are often associated with dysregulation of dendritic spines (Benarroch, 2007; Laumonnier et al., 
2007). For example, Patau syndrome (trisomy 13), Down syndrome (trisomy 21), and fragile $\mathrm{X}$ all have alterations in the number and shape of dendritic spines (Kaufmann and Moser, 2000; Govek et al., 2004; Grossman et al., 2006). Understanding why a subset of behaviors is affected by loss of Kal7 whereas other learning tasks are not affected should provide new insights into signaling.

\section{Comparing in vitro and in} vivo phenotypes

As observed for other PSD protein knock-out mice (Migaud et al., 1998; Elias et al., 2006; Varoqueaux et al., 2006), the phenotype of the $\mathrm{Kal} 7^{\mathrm{KO}}$ mouse is less severe than would have been predicted from in vitro studies. Several factors may contribute to this difference. Most importantly, alternative splicing allows the larger isoforms of $\mathrm{Ka}$ lirin to accumulate in $\mathrm{Kal} 7^{\mathrm{KO}}$ neurons. Lacking the Kal7 exon, the splicing machinery associated with Kalirin transcripts would be expected to splice exon 33 to exon 34, creating the increased levels of Kal8, Kal9, and Kal12 in total homogenates (Fig. 5E-G). The other targeting strategy considered, insertion of a stop codon within the Kal7 exon preceding the PDZ binding motif, would have generated a truncated product, complicating analysis in a different manner. Because the Sec14p and spectrin-like repeats target Kalirin to membranes, the nine copies of Kal7 present at the "typical" synapse in wild-type mice may be replaced by six copies of these larger Kalirin isoforms, which could help preserve excitatory synapses and alter synaptic function in a region- and contextspecific manner.

Recent studies assigning an essential role for Kal7 in activity-dependent activation of the Rac and N-cadherin/afadin pathways used an shRNA directed against the spectrin repeat region (nucleotides 1229-1250; spectrins 2-3) (Xie et al.,

2007, 2008), reducing expression of all major forms of Kalirin, not just Kal7. Although this approach led to the conclusion that Kal7 regulates the GluR1 content of pyramidal neuron dendritic spines and AMPA receptor-mediated synaptic transmission (Xie et al., 2007), the GluR1 content of PSDs purified from Kal7 ${ }^{\mathrm{KO}}$ neurons is indistinguishable from wild-type. Selective elimination of Kal7 using antisense or shRNA targeted to its unique 3 '-untranslated region ( $\mathrm{Ma}$ et al., 2008) produced a more profound decrease in spine density (approximately twofold) than observed in cultures prepared from Kal7 ${ }^{\mathrm{KO}}$ mice. A Kal7-specific shRNA would not be expected to increase levels of the larger kalirin isoforms; in addition, breakdown products generated from Kal7 transcripts targeted by the shRNA could contribute to the effects observed (Kim and Rossi, 2008). indicate SEM.
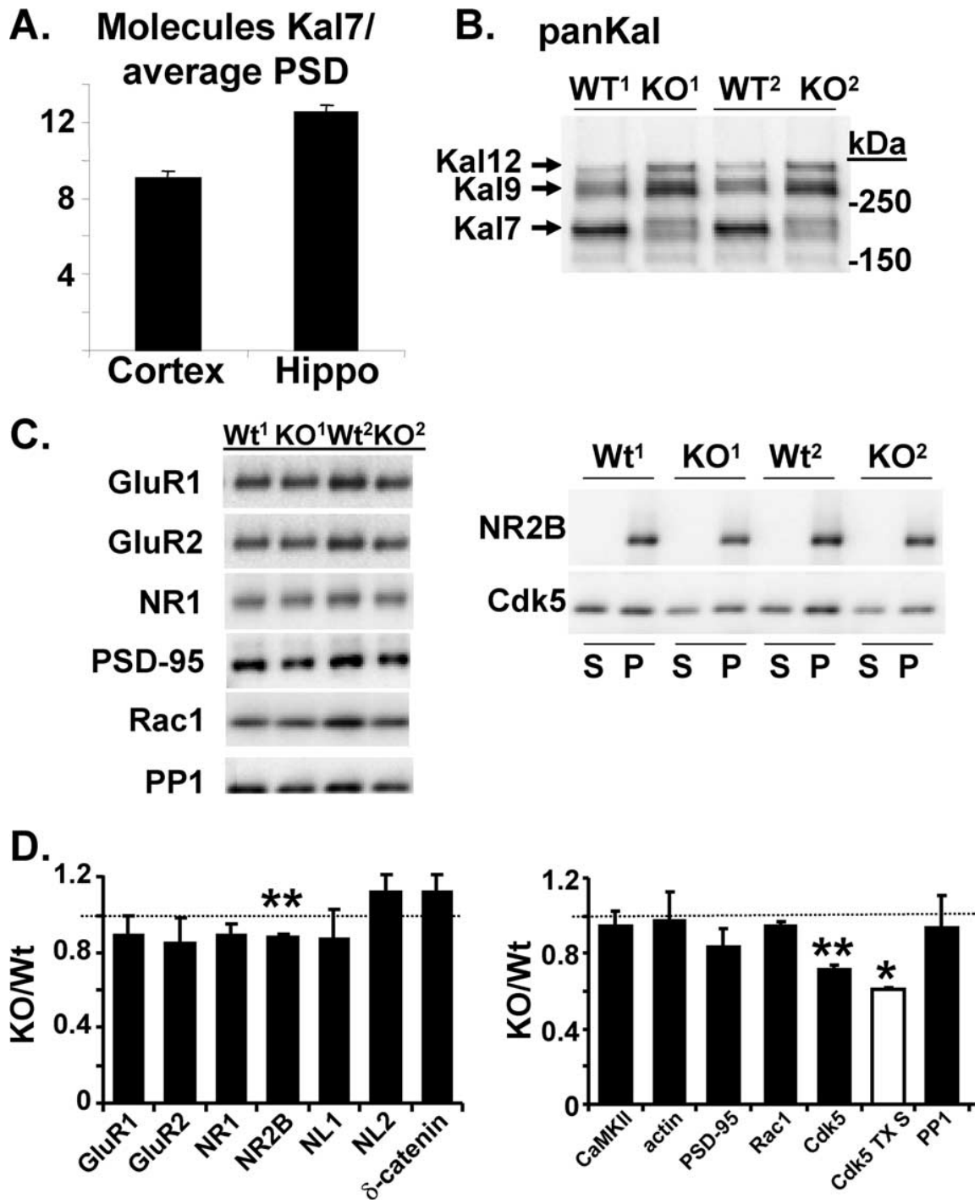

Figure 8. PSD preparations from Wt and Kal $7{ }^{\mathrm{K} 0}$ mice. $A$, Purified $\Delta \mathrm{Kal} 7 \mathrm{was}$ used to quantify the amount of Kal7 in the average 1.1 GDa PSD (Collins et al., 2006; Sheng and Hoogenraad, 2007). Recombinant purified $\Delta$ Kal7 was quantified by making a dilution series and comparing Coomassie Blue staining to a bovine serum albumin standard of known concentration. Western blot signals, using affinity-purified Kal7 antibody, for the $\Delta$ Kal7 standard were used to construct a standard curve to quantify Kal7 in the PSD samples. $\boldsymbol{B}$, Use of the pan-Kalirin antibody revealed that PSDs (5 $\mu \mathrm{g}$ of protein) prepared from Kal7 ${ }^{\mathrm{K} 0}$ mice had increased levels of Kal9 and Kal12 compared with PSD s prepared from Wt mice. C, Left, PSDs (5 $\mu \mathrm{g}$ of protein) purified from the cortices of two sets a $\mathrm{Kal}{ }^{\mathrm{KO}}$ mice were blotted for AMPA and NMDA receptor subunits, neuroligins 1 and 2, $\delta$-catenin, and for the Kal7 interactors PSD-95, Rac1, and PP1. Right, Both the Triton-soluble (S) and insoluble PSD (P) fractions were blotted for NR2B and Cdk5. D, Data from three sets of Wt and Kal7 ${ }^{\mathrm{K} 0}$ PSDs were averaged $\left(n=2\right.$ for $\left(\mathrm{dk} 5 \mathrm{TX}\right.$ S); ${ }^{*} p<0.05 ;{ }^{* *} p<0.01$. Error bars

Spine and plasticity analysis

Ultrastructural analyses demonstrated a substantial decrease in the number of synapses (PSD with presynaptic terminal) in CA1 hippocampal neurons from $\mathrm{Kal} 7{ }^{\mathrm{KO}}$ mice. Our cell culture data showed a similar decline in synapses assessed as Vglut1/PSD-95 clusters (Fig. 9). Golgi staining revealed a less dramatic decrease in linear spine density. Although Vglut1-positive terminals in wild-type neurons usually align with PSD-95 clusters, this strict association is lost in Kal7 ${ }^{\mathrm{KO}}$ neurons (Fig. 9H). Neither unpaired spine-like structures nor unpaired presynaptic endings would be counted by EM analysis. The PSDs in Kal ${ }^{\mathrm{KO}}$ mice were narrower and thinner than in wild-type mice. These changes in PSD dimensions were consistent and comparable with changes seen in Shank1 ${ }^{\mathrm{KO}}$ mice (Hung et al., 2008). 

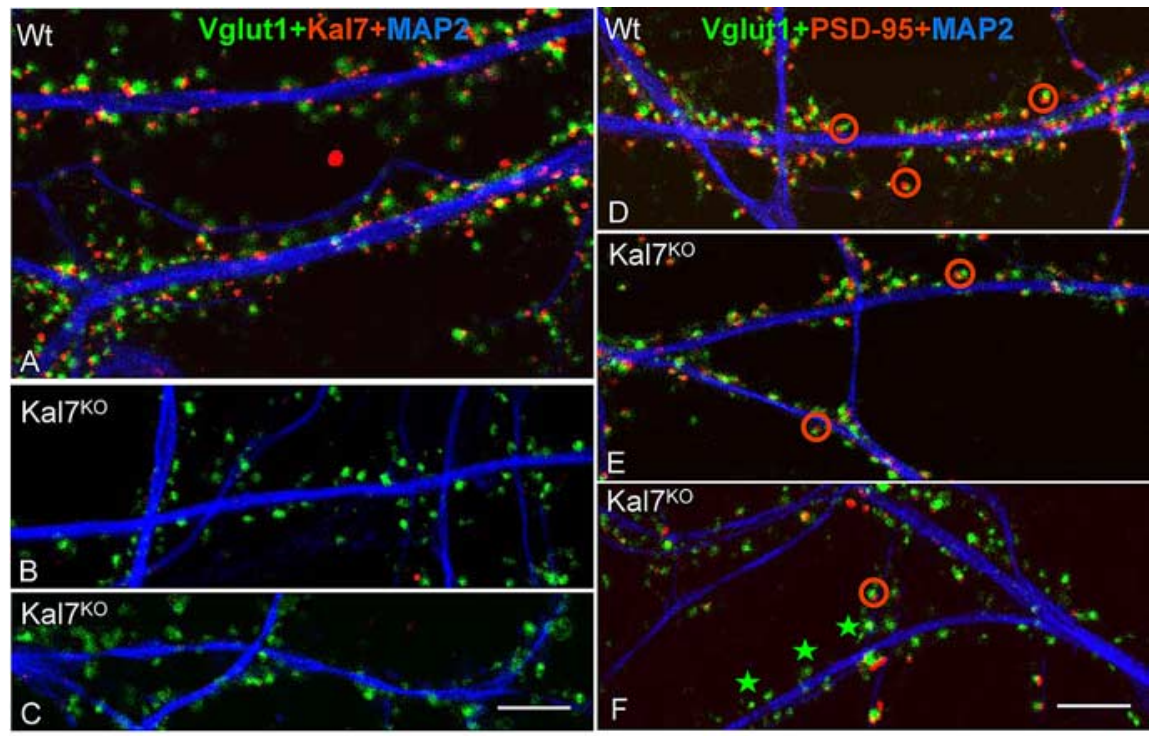

G.
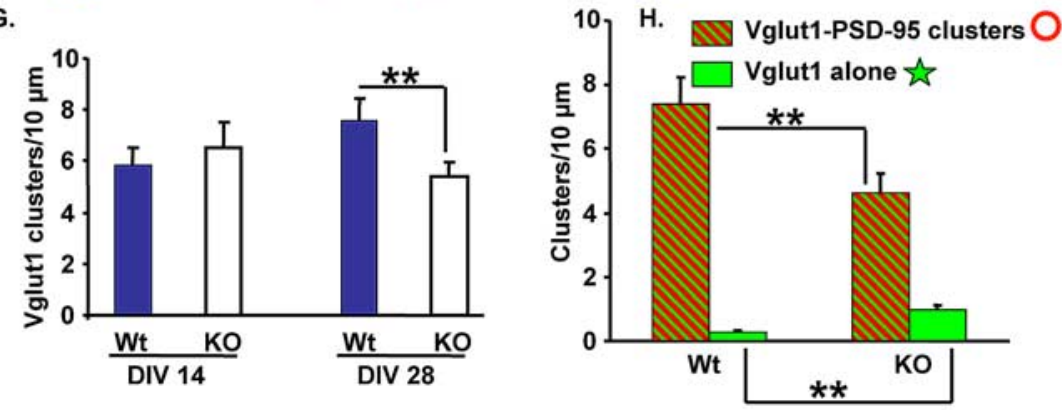

Figure 9. Decreased number of synapses in the mature Kal ${ }^{\mathrm{K} 0}$ neurons in culture. Cortical cultures were prepared from $\mathrm{P} 1$ littermate wild-type and Kal $7{ }^{\mathrm{K} 0}$ mice. Replicate cultures were fixed at DIV7 (supplemental Fig. S5A, available at www.jneurosci.org as supplemental material), DIV14 (supplemental Fig. S5B, available at www.jneurosci.org as supplemental material), DIV21 (images not shown), and DIV28 $(\boldsymbol{A}-\boldsymbol{F})$. One set of cultures was visualized with antibodies specific to Vglut1, MAP2, and Kal7 (A-C); the other set was visualized with antibodies to Vglut1, MAP2, and PSD-95 (D-F). Clusters of Vglut1, Kal7, and PSD-95 staining were quantified by observers blinded to genotype. Differences in number of Vglut1-only clusters (excitatory presynaptic terminals; green stars) or number of excitatory synapses (Vglut1-PSD-95 clusters; red circles) between wild-type and Kal7 ${ }^{\mathrm{KO}}$ mice were only detected at $\operatorname{DIV} 28(\mathbf{G}, \boldsymbol{H})\left(n=9-12\right.$ for Wt; $n=10-12$ for K0). Scale bar, $5 \mu \mathrm{m}$. Error bars indicate SEM; ${ }^{* *} p<0.01$.

Tracking the development of synapses in cortical cultures prepared from Kal7 ${ }^{\mathrm{KO}}$ mice was revealing. Both in vivo and in culture, synapses begin to form before Kal7 is expressed. Synaptic development proceeded normally for $21 \mathrm{~d}$ in the absence of Kal7; Vglut1-positive presynaptic endings contacted dendritic shafts aligned with PSD-95 clusters. Although spine density increased between DIV21 and DIV28 in wild-type neurons, no increase was observed in $\mathrm{Kal}^{\mathrm{KO}}$ neurons; it is not clear what distinguishes the spines formed between P21 and P28. Kal7 may play an essential role in the maturation and/or maintenance of dendritic spines, as proposed for the neuroligins (Varoqueaux et al., 2006). Consistent with the conclusion that Kal7 has a role late in synaptic development, no differences in LTP were apparent when slices from P21 and younger mice were examined. When synaptic plasticity was tested in Kal7 ${ }^{\mathrm{KO}}$ mice older than P28, deficits were apparent (Fig. 4).

Although PSD length and width were reduced in $\mathrm{Kal} 7{ }^{\mathrm{KO}}$ mice, the effect was small, consistent with our inability to see dramatic changes in PSD content of a number of proteins. Indeed, similar results have been seen with other PSD-protein knock-outs. Ablation of PSD-95 caused no change in spine volume, but made spines longer and thinner and decreased the number of AMPA receptors (Béique et al., 2006; Elias et al., 2006). Knock-out of
Shank1, which caused a decrease in spine number and PSD size, decreased levels of GKAP (guanylate kinase-associated protein) and Homer and weakened basal synaptic transmission, leaving synaptic plasticity unaltered (Hung et al., 2008).

\section{Potential mechanisms}

Determining how the absence of Kal7 causes these changes in spine number and synaptic function will require detailed analysis of the deficits. Kal7 ${ }^{\mathrm{KO}}$ PSDs contained less Cdk5 and less NR2B than wildtype PSDs. Cdk5 plays a complex and important role in postsynaptic signaling and architecture (Benavides and Bibb, 2004; Cheung et al., 2006; Cheung and Ip, 2007) and the decrease in Cdk5 may contribute to many of the changes observed. For example, the GEF activity of Kal7 is increased after Cdk5-catalyzed phosphorylation of $\mathrm{Thr}^{1590}$ (Xin et al., 2008). Although Kal7 with either a $\mathrm{T}^{1590} \mathrm{~A}$ or $\mathrm{T}^{1590} \mathrm{D}$ mutation caused spine formation when expressed in rat cortical neurons, spine morphologies differed (Xin et al., 2008). Based on the fact that dominant-negative Cdk5 blocked the ability of Kal7 to affect PC12 cell morphology, this interaction appears to play a critical role in Kalirin function.

Like Kal7, the Cdk5/p35 complex affects Rac/Pak signaling (Nikolic et al., 1998), which alters cytoskeletal dynamics in dendritic spines (Tashiro et al., 2000). Through its effects on ephrins, the decreased Cdk5 in Kal7 ${ }^{\mathrm{KO}}$ PSDs may contribute to the dearth of dendritic spines. Cdk5 plays a role in EphA-dependent spine retraction (Fu et al., 2007), whereas Kal7 plays a role in EphB-dependent spine maturation (Penzes et al., 2003). Cdk5 phosphorylates PSD-95, regulating its clustering (Morabito et al., 2004), which might contribute to the changes in PSD size and shape seen in $\mathrm{Kal}{ }^{\mathrm{KO}}$ mice. Importantly, Cdk5 plays a role in the phosphorylation of NR2B, resulting in its stabilization in the membrane (Zhang et al., 2008). The decreased levels of Cdk5 in Kal7 ${ }^{\mathrm{KO}}$ PSDs may cause the decreased levels of NR2B. Additional studies are underway to determine how Kal7 and Cdk5 interact to contribute to the changes observed in $\mathrm{Kal} 7^{\mathrm{KO}}$ mice.

\section{Kal7 is essential for specific memory processes}

Given the spine changes seen in mental retardation and the role of dendritic spines in memory formation (Benarroch, 2007), it is not surprising that $\mathrm{Kal} 7^{\mathrm{KO}}$ animals exhibit learning deficits. Although numerous knock-out mice have demonstrated deficits in hippocampal learning processes, few have revealed disparities in appetitive spatial and aversive contextual hippocampaldependent learning paradigms (Bach et al., 1995; Hung et al., 2008). It has been posited that different mechanisms underlie single-trial versus more gradual repetitively learned tasks (Bach et al., 1995; Hung et al., 2008). The Kal7 ${ }^{\mathrm{KO}}$ mice were normal in nonaversive tests of learning and memory (object recognition, radial arm maze), but abnormal in tests of anxiety and fear learn- 
ing (elevated zero maze, passive avoidance). Perhaps specific proteins or signaling pathways are essential for the formation/function of synapses necessary for particular types of learning (e.g., fear learning) but not others (e.g., spatial learning). The hypothesis that specific synapses or molecular pathways underlie different forms of hippocampal memory was put forth previously (Bach et al., 1995), but has received little additional investigation. Future behavioral and neurochemical mapping studies of $\mathrm{Kal}^{\mathrm{KO}}$ and $\mathrm{Kal} 7^{\mathrm{CKO}}$ mice will help clarify the role of different spine proteins in different types of learning.

\section{Kal7 plays a key role in synaptic plasticity and in human psychiatric conditions}

Kal7 is the only RhoGEF specifically trafficked to the PSD (Sheng and Hoogenraad, 2007) and the only RhoGEF identified in the complex of NR2B-associated proteins (Collins et al., 2006). Decreased levels of Kal7 were observed in postmortem cortices from schizophrenics and Alzheimer disease patients (Tataki et al., 2005; Hill et al., 2006; Youn et al., 2007). In addition to the present findings, preliminary studies with $\mathrm{Kal} 7^{\mathrm{KO}}$ mice revealed aberrant responses to drugs of abuse and additional deficits in synaptic plasticity and cognitive function. Kal7 ${ }^{\mathrm{KO}}$ mice have now emerged as a valuable model for understanding synaptic malfunctions and human psychiatric disorders.

\section{References}

Araya R, Nikolenko V, Eisenthal KB, Yuste R (2007)

Sodium channels amplify spine potentials. Proc

Natl Acad Sci U S A 104:12347-12352.

Bach ME, Hawkins RD, Osman M, Kandel ER, Mayford M (1995) Impairment of spatial but not contextual memory in CaMKII mutant mice with a selective loss of hippocampal LTP in the range of the theta frequency. Cell 81:905-915.

Bannerman DM, Niewoehner B, Lyon L, Romberg C, Schmitt WB, Taylor A, Sanderson DJ, Cottam J, Sprengel R, Seeburg PH, Köhr G, Rawlins JN (2008) NMDA receptor subunit NR2A is required for rapidly acquired spatial working memory but not incremental spatial reference memory. J Neurosci 28:3623-3630.

Béique JC, Lin DT, Kang MG, Aizawa H, Takamiya K, Huganir RL (2006) Synapse-specific regulation of AMPA receptor function by PSD-95. Proc Natl Acad Sci U S A 103:19535-19540.

Benarroch EE (2007) Rho GTPases: role in dendrite and axonal growth, mental retardation, and axonal regeneration. Neurology 68:1315-1318.

Benavides DR, Bibb JA (2004) Role of cdk5 in drug abuse and plasticity. Ann N Y Acad Sci 1025:335-344.

Carlin RK, Grab DJ, Cohen RS, Siekevitz P (1980) Isolation and characterization of postsynaptic densities from various brain regions: enrichment of different types of postsynaptic densities. J Cell Biol 86:831-845.

Cheng D, Hoogenraad CC, Rush J, Ramm E, Schlager MA, Duong DM, Xu P, Wijayawardana SR, Hanfelt J, Nakagawa T, Sheng M, Peng J (2006) Relative and absolute quantification of postsynaptic density proteome isolated from rat forebrain and cerebellum. Mol Cell Proteomics 5:1158-1170.

Cheung ZH, Ip NY (2007) The roles of cyclin-dependent kinase 5 in dendrite and synapse development. Biotech J 2:949-957.

Cheung ZH, Fu AK, Ip NY (2006) Synaptic roles of cdk5: implications in higher cognitive functions and neurodegenerative diseases. Neuron 50:13-18

Chubykin AA, Atasoy D, Etherton MR, Brose N, Kavalali ET, Gibson JR, Südhof TC (2007) Activity-dependent validation of excitatory versus inhibitory synapses by neuroligin-1 versus neuroligin-2. Neuron 54:919-931.

Collins MO, Husi H, Yu L, Brandon JM, Choudhary JS, Grant SGN (2006) Molecular characterization and comparison of the components and multiprotein complexes in the postsynaptic proteome. J Neurochem 97 [Suppl 1]:16-23.

Craig AM, Kang YH (2007) Neurexin-neuroligin signaling in synapse development. Curr Opin Neurobiol 17:43-52.

Craig AM, Graf ER, Linhoff MW (2006) How to build a central synapse: clues from cell culture. Trends Neurosci 29:8-20.

Dunaevsky A, Mason CA (2003) Spine motility: a means toward an end? Trends Neurosci 26:155-160.

Duvarci S, Nader K, LeDoux JE (2005) Activation of extracellular signalregulated kinase-mitogen-activated protein kinase cascade in the amygdala is required for memory reconsolidation of auditory fear conditioning. Eur J Neurosci 21:283-289.

Ehlers MD (2002) Molecular morphogens for dendritic spines. Trends Neurosci 25:64-67.

Elias GM, Funke L, Stein V, Grant SG, Bredt DS, Nicoll RA (2006) Synapsespecific and developmentally regulated targeting of AMPA receptors by a family of MAGUK scaffolding proteins. Neuron 52:307-320.

Farley FW, Soriano P, Steffen LS, Dymecki SM (2000) Widespread recombinase expression using FLPeR (flipper) mice. Genesis 28:106-110.

Fu WY, Chen Y, Sahin M, Zhao XS, Shi L, Bikoff JB, Lai KO, Yung WH, Fu 
AK, Greenberg ME, Ip NY (2007) Cdk5 regulates EphA4-mediated dendritic spine retraction through an ephexin1-dependent mechanism. Nat Neurosci 10:67-76.

Fukazawa Y, Saitoh Y, Ozawa F, Ohta Y, Mizuno K, Inokuchi K (2003) Hippocampal LTP is accompanied by enhanced F-actin content within the dendritic spine that is essential for late LTP maintenance in vivo. Neuron 38:447-460.

Geinisman Y, Disterhoft JF, Gundersen HJ, McEchron MD, Persina IS, Power JM, van der Zee EA, West MJ (2000) Remodeling of hippocampal synapses after hippocampus-dependent associative learning. J Comp Neurol 417:49-59.

Govek EE, Newey SE, Akerman CJ, Cross JR, Van der Veken L, Van Aelst L (2004) The X-linked mental retardation protein oligophrenin-1 is required for dendritic spine morphogenesis. Nat Neurosci 7:364-372.

Grossman AW, Aldridge GM, Weiler IJ, Greenough WT (2006) Local protein synthesis and spine morphogenesis: fragile $\mathrm{X}$ syndrome and beyond. J Neurosci 26:7151-7155.

Harris KM, Stevens JK (1989) Dendritic spines of CA 1 pyramidal cells in the rat hippocampus: serial electron microscopy with reference to their biophysical characteristics. J Neurosci 9:2982-2997.

Hawasli AH, Benavides DR, Nguyen C, Kansy JW, Hayashi K, Chambon P, Greengard P, Powell CM, Cooper DC, Bibb JA (2007) Cyclindependent kinase 5 governs learning and synaptic plasticity via control of NMDAR degradation. Nat Neurosci 10:880-886.

Hill JJ, Hashimoto T, Lewis DA (2006) Molecular mechanisms contributing to dendritic spine alterations in the prefrontal cortex of subjects with schizophrenia. Mol Psychiatry 11:557-566.

Hung AY, Futai K, Sala C, Valtschanoff JG, Ryu J, Woodworth MA, Kidd FL, Sung CC, Miyakawa T, Bear MF, Weinberg RJ, Sheng M (2008) Smaller dendritic spines, weaker synaptic transmission, but enhanced spatial learning in mice lacking Shank1. J Neurosci 28:1697-1708.

Huttner WB, Schiebler W, Greengard P, De Camilli P (1983) Synapsin I (protein I), a nerve terminal-specific phosphoprotein. III. Its association with synaptic vesicles studied in a highly purified synaptic vesicle preparation. J Cell Biol 96:1374-1388.

Inoue M, Hashimoto Y, Kudo Y, Miyakawa H (2001) Dendritic attenuation of synaptic potentials in the CA1 region of rat hippocampal slices detected with an optical method. Eur J Neurosci 13:1711-1721.

Jelks KB, Wylie R, Floyd CL, McAllister AK, Wise P (2007) Estradiol targets synaptic proteins to induce glutamatergic synapse formation in cultured hippocampal neurons: critical role of estrogen receptor-alpha. J Neurosci 27:6903-6913.

Johnson RC, Penzes P, Eipper BA, Mains RE (2000) Isoforms of kalirin, a neuronal Dbl family member, generated through use of different $5^{\prime}$ - and $3^{\prime}$-ends along with an internal translational initiation site. J Biol Chem 275:19324-19333.

Kauer JA, Malenka RC (2007) Synaptic plasticity and addiction. Nat Rev Neurosci 8:844-858.

Kaufmann WE, Moser HW (2000) Dendritic anomalies in disorders associated with mental retardation. Cereb Cortex 10:981-991.

Kim D, Rossi J (2008) RNAi mechanisms and applications. Biotechniques 44:613-616.

Knott GW, Holtmaat A, Wilbrecht L, Welker E, Svoboda K (2006) Spine growth precedes synapse formation in the adult neocortex in vivo. Nat Neurosci 9:1117-1124.

Kosik KS, Donahue CP, Israely I, Liu X, Ochiishi T (2005) Delta-catenin at the synaptic-adherens junction. Trends Cell Biol 15:172-178.

Laumonnier F, Cuthbert PC, Grant SGN (2007) The role of neuronal complexes in human X-linked brain diseases. Am J Hum Genet 80:205-220.

Li C, Brake WG, Romeo RD, Dunlop JC, Gordon M, Buzescu R, Magarinos AM, Allen PB, Greengard P, Luine V, McEwen BS (2004) Estrogen alters hippocampal dendritic spine shape and enhances synaptic protein immunoreactivity and spatial memory in female mice. Proc Natl Acad Sci U S A 101:2185-2190.

Lisman J, Raghavachari S (2006) A unified model of the presynaptic and postsynaptic changes during LTP at CAl synapses. Science STKE 2006:re11.

Ma XM, Johnson RC, Mains RE, Eipper BA (2001) Expression of Kalirin, a neuronal GDP/GTP exchange factor of the Trio family, in the central nervous system of the adult rat. J Comp Neurol 429:388-402.

Ma XM, Mains RE, Eipper BA (2002) Plasticity in hippocampal peptidergic systems induced by repeated electroconvulsive shock. Neuropsychopharmacology 27:55-71.

Ma XM, Huang J, Wang Y, Eipper BA, Mains RE (2003) Kalirin, a multifunctional Rho GEF, is necessary for maintenance of hippocampal pyramidal neuron dendrites and dendritic spines. J Neurosci 23:10593-10603.

Ma XM, Wang Y, Ferraro F, Mains RE, Eipper BA (2008) Kalirin-7 is an essential component of both shaft and spine excitatory synapses in hippocampal interneurons. J Neurosci 28:711-724.

Mainen ZF, Carnevale NT, Zador AM, Claiborne BJ, Brown TH (1996) Electrotonic architecture of hippocampal CA1 pyramidal neurons based on three-dimensional reconstructions. J Neurophysiol 76:1904-1923.

McAllister AK (2007) Dynamic aspects of CNS synapse formation. Annu Rev Neurosci 30:425-450.

McPherson CE, Eipper BA, Mains RE (2002) Genomic organization and differential expression of Kalirin isoforms. Gene 284:41-51.

McPherson CE, Eipper BA, Mains RE (2005) Multiple novel isoforms of Trio are expressed in the developing rat brain. Gene 347:125-135.

Meredith GE, De Souza IE, Hyde TM, Tipper G, Wong ML, Egan MF (2000) Persistent alterations in dendrites, spines, and dynorphinergic synapses in the nucleus accumbens shell of rats with neuroleptic-induced dyskinesias. J Neurosci 20:7798-7806.

Mezey S, Doyère V, De Souza I, Harrison E, Cambon K, Kendal CE, Davies H, Laroche S, Stewart MG (2004) Long-term synaptic morphometry changes after induction of long-term potentiation and long-term depression in the dentate gyrus of awake rats are not simply mirror phenomena. Eur J Neurosci 19:2310-2318.

Migaud M, Charlesworth P, Dempster M, Webster LC, Watabe AM, Makhinson M, He Y, Ramsay MF, Morris RG, Morrison JH, O’Dell TJ, Grant SG (1998) Enhanced long-term potentiation and impaired learning in mice with mutant postsynaptic density-95 protein. Nature 396:433-439.

Morabito MA, Sheng M, Tsai LH (2004) Cyclin-dependent kinase 5 phosphorylates the N-terminal domain of the postsynaptic density protein PSD-95 in neurons. J Neurosci 24:865-876.

Nikolic M, Chou MM, Lu W, Mayer BJ, Tsai LH (1998) The p35/Cdk5 kinase is a neuron-specific Rac effector that inhibits Pak1 activity. Nature 395:194-198.

Norrholm SD, Ouimet CC (2000) Chronic fluoxetine administration to juvenile rats prevents age-associated dendritic spine proliferation in hippocampus. Brain Res 883:205-215.

Norrholm SD, Bibb JA, Nestler EJ, Ouimet CC, Taylor JR, Greengard P (2003) Cocaine-induced proliferation of dendritic spines in nucleus accumbens is dependent on the activity of cyclin-dependent kinase-5. Neuroscience 116:19-22.

Ochiishi T, Futai K, Okamoto K, Kameyama K, Kosik KS (2008) Regulation of AMPA receptor trafficking by delta-catenin. Mol Cell Neurosci. Advance online publication. Retrieved August 29, 2008. doi:10.1016/j.mcn.2008.06.002.

Paré D, Quirk GJ, Ledoux JE (2004) New vistas on amygdala networks in conditioned fear. J Neurophysiol 92:1-9.

Penzes P, Johnson RC, Sattler R, Zhang X, Huganir RL, Kambampati V, Mains RE, Eipper BA (2001) The neuronal Rho-GEF Kalirin-7 interacts with PDZ domain-containing proteins and regulates dendritic morphogenesis. Neuron 29:229-242.

Penzes P, Beeser A, Chernoff J, Schiller MR, Eipper BA, Mains RE, Huganir RL (2003) Rapid induction of dendritic spine morphogenesis by transsynaptic ephrinB-EphB receptor activation of the Rho-GEF kalirin. Neuron 37:263-274.

Pogorelov VM, Rodriguiz RM, Insco ML, Caron MG, Wetsel WC (2005) Novelty seeking and stereotypic activation of behavior in mice with disruption of the Dat1 gene. Neuropsychopharmacology 30:1818-1831.

Ramakers GJA (2000) Rho proteins and the cellular mechanisms of mental retardation. Am J Med Genet 94:367-371.

Robinson TE, Gorny G, Mitton E, Kolb B (2001) Cocaine selfadministration alters the morphology of dendrites and dendritic spines in the nucleus accumbens and neocortex. Synapse 39:257-266.

Rossman KL, Der CJ, Sondek J (2005) GEF means go: turning on Rho GTPases with guanine nucleotide-exchange factors. Nat Rev Mol Cell Biol 6:167-180.

Schiller MR, Blangy A, Huang J, Mains RE, Eipper BA (2005) Induction of lamellipodia by Kalirin does not require its guanine nucleotide exchange factor activity. Exp Cell Res 307:402-417.

Schiller MR, Ferraro F, Wang Y, Ma XM, McPherson CE, Sobota JA, Schiller 
NI, Mains RE, Eipper BA (2008) Autonomous functions for the Sec14p/ spectrin-repeat region of Kalirin. Exp Cell Res 314:2674-2691.

Sheng M, Hoogenraad CC (2007) The postsynaptic architecture of excitatory synapses: a more quantitative view. Annu Rev Biochem 76:823-847.

Sugiyama Y, Kawabata I, Sobue K, Okabe S (2005) Determination of absolute protein numbers in single synapses by a GFP-based calibration technique. Nat Methods 2:677-684.

Tabuchi K, Blundell J, Etherton MR, Hammer RE, Liu X, Powell CM, Südhof TC (2007) A neuroligin-3 mutation implicated in autism increases inhibitory synaptic transmission in mice. Science 318:71-76.

Tashiro A, Minden A, Yuste R (2000) Regulation of dendritic spine morphology by the rho family of small GTPases: antagonistic roles of Rac and Rho. Cereb Cortex 10:927-938.

Tataki M, Paek M, Kamiya A, Balkissoon R, Tomoda T, Penzes P, Sawa A (2005) Disrupted-in-schizophrenia-1 (DISC1) binds to Kalirin-7 and modulates its function as a GDP/GEP exchange factor. Soc Neurosci Abstr 31:674.9.

Varoqueaux F, Aramuni G, Rawson RL, Mohrmann R, Missler M, Gottmann K, Zhang W, Südhof TC, Brose N (2006) Neuroligins determine synapse maturation and function. Neuron 51:741-754.
Xie Z, Srivastava DP, Photowala H, Kai L, Cahill ME, Woolfrey KM, Shum CY, Surmeier DJ, Penzes P (2007) Kalirin-7 controls activity-dependent structural and functional plasticity of dendritic spines. Neuron 56:640-656.

Xie Z, Photowala H, Cahill ME, Srivastava DP, Woolfrey KM, Shum CY, Huganir RL, Penzes P (2008) Coordination of synaptic adhesion with dendritic spine remodeling by AF-6 and Kalirin-7. J Neurosci 28:6079-6091.

Xin X, Wang Y, Ma XM, Rompolas P, Keutmann HT, Mains RE, Eipper BA (2008) Regulation of kalirin by cdk5. J Cell Sci 121:2601-2611.

Youn HS, Jeoung MK, Koo YB, Ji H, Markesbery WR, Ji I, Ji TH (2007) Kalirin is under-expressed in Alzheimer's disease hippocampus. J Alzheimers Dis 11:385-397.

Yuste R, Bonhoeffer T (2001) Morphological changes in dendritic spines associated with long-term synaptic plasticity. Annu Rev Neurosci 24:1071-1089.

Zhang S, Edelmann L, Liu J, Crandall JE, Morabito MA (2008) Cdk5 regulates the phosphorylation of 1472 NR2B and the surface expression of NMDA receptors. J Neurosci 28:415-424.

Zhou WL, Yan P, Wuskell JP, Loew LM, Antic SD (2008) Dynamics of action potential backpropagation in basal dendrites of prefrontal cortical pyramidal neurons. Eur J Neurosci 27:923-936. 